\title{
DOCTRINA DEL TRIBUNAL CONSTITUCIONAL DURANTE EL PRIMER CUATRIMESTRE DE 2020
}

Doctrine of the Constitutional Court during the first four-month period of 2020

\author{
JUAN CARLOS DUQUE VILLANUEVA \\ Tribunal Constitucional \\ duque@tribunalconstitucional.es
}

\section{CARLOS ORTEGA CARBALLO}

Tribunal de Cuentas

ortega@tribunalconstitucional.es

\section{HERMINIO LOSADA GONZÁLEZ}

Tribunal Constitucional

losada@tribunalconstitucional.es

\section{TOMÁS DE LA QUADRA-SALCEDO JANINI \\ Tribunal Constitucional \\ tquadra@tribunalconstitucional.es}


I. JURISDICCIÓN CONSTITUCIONAL. DERECHO PROCESAL CONSTITUCIONAL.

II. FUENTES DEL DERECHO. III. ORGANIZACIÓN TERRITORIAL DEL ESTADO. IV. DERECHOS FUNDAMENTALES.

\section{JURISDICCIÓN CONSTITUCIONAL. DERECHO PROCESAL CONSTITUCIONAL}

El primer cuatrimestre del año 2020, período que abarca esta crónica de jurisprudencia constitucional, ha venido marcado por la parcial paralización de la actividad del TC, en lo que al dictado de sentencias se refiere, como consecuencia de la declaración del estado de alarma - 14 de marzo - para la gestión de la crisis sanitaria ocasionada por la covid-19. En el meollo de esta situación se ha elaborado la crónica que ahora se ofrece en estas páginas, en la que se da cuenta, por la razón expuesta, de un menor número de resoluciones respecto a lo que es común en las crónicas de otros cuatrimestres.

1. En la STC 16/2020 (Pleno), de 28 de enero ${ }^{1}$, se desestima la extemporaneidad del recurso de inconstitucionalidad denunciada por el Gobierno de la comunidad autónoma autora de la norma impugnada porque uno de los preceptos incluidos en el acuerdo de iniciación de negociaciones del art. 33 LOTC no había sido objeto de una negociación efectiva. El TC considera que «[e]l alcance objetivo o la necesidad de esa negociación no están mencionados en nuestra Ley Orgánica reguladora y, por esta razón, no pueden tener efectos con relación a la admisibilidad del recurso», no existiendo ningún requisito adicional a los expresamente previstos en el art. 33.2 LOTC para la admisión del recurso de inconstitucionalidad. Asimismo, reproduciendo la doctrina de la STC 14/2015, de 5 de febrero, se recuerda que el art. 33 LOTC no impone que las negociaciones «hayan de prolongarse durante la totalidad del plazo ampliado de nueve meses, ni tampoco que hayan de explicitarse las razones que llevan a la parte actora [...] a considerar que dichas negociaciones no pueden conducir a una avenencia [...] decidiendo, por tanto, interponer el recurso antes de la expiración del mencionado plazo de nueves meses» (FJ 3a).

1 Véanse infra pp. 242-246. 
Idéntico resultado desestimatorio tuvo como causa de inadmisión del recurso de inconstitucionalidad la alegada «falta de impugnación de disposiciones o actuaciones previas de contenido idéntico o similar al objeto del proceso». Tal circunstancia — señala el TC— «resulta completamente irrelevante en el ejercicio de nuestra jurisdicción", pues, de un lado, con el recurso de inconstitucionalidad, dado su carácter abstracto, «no se defiende un interés propio de los recurrentes, sino el interés general y la supremacía de la Constitución", y, por otro lado, la doctrina de la indisponibilidad de las competencias y de la nulidad de pleno derecho de las normas contrarias a los preceptos constitucionales, son razones que «desautorizan cualquier alegato sentado sobre la idea de la aquiescencia por no haberse planteado en el tiempo el conflicto o el recurso, con sujeción al juego de los plazos previstos» en la LOTC (FJ 3b).

2. Durante este cuatrimestre, al igual que en el anterior, se han vuelto a resolver otros cinco incidentes de ejecución de las SSTC 259/2015 (Pleno), de 2 de diciembre ${ }^{2}$, 136/2018 (Pleno), de 13 de diciembre ${ }^{3}$, y 98/2019 (Pleno), de $17 \mathrm{de} \mathrm{julio}^{4}$, en las que se había declarado la inconstitucionalidad y nulidad de diversas resoluciones aprobadas por el Parlamento de Cataluña vinculadas al proceso independentista ${ }^{5}$.

El TC desestima los óbices de admisibilidad a los incidentes de ejecución opuestos por el letrado del Parlamento de Cataluña, así como por los miembros de la Mesa y los diputados personados en el incidente. Declara, en primer lugar, que en el recurso de súplica contra la decisión de admisión de los incidentes únicamente puede controvertirse el cumplimiento de los requisitos procesales para la promoción de los incidentes de ejecución, sin que en ningún caso puedan aducirse razones de fondo para cuestionar su procedibilidad; es decir, el recurso de súplica contra la decisión de admisión «no puede fundarse en cualesquiera motivos, sino que estos deben guardar relación con los aspectos sobre los que ha versado el juicio de admisibilidad efectuado por el Tribunal en ese momento procesal».

Asimismo, el TC rechaza el alegato de que los incidentes deben inadmitirse por dirigirse contra actos de trámite (decisiones de la Mesa del Parlamento

2 Reseñada en Revista Española de Derecho Constitucional, núm. 101 (2014), pp. 235-237.

3 Reseñada en Revista Española de Derecho Constitucional, núm. 106 (2016), pp. 343-343 y 356.

4 Reseñada en Revista Española de Derecho Constitucional, núm. 115 (2019), pp. 256-257.

5 Véase Revista Española de Derecho Constitucional, núm. 118 (2020), pp. 224-225. 
por las que se admiten a trámite determinadas propuestas de resolución o mociones), que desplegarían sus efectos en la esfera interna del procedimiento parlamentario en el que se insertan y que solo cobrarían relevancia ad extra cuando las propuestas de resolución o mociones fueran aprobadas por el Pleno de la Cámara. El TC entiende que ciertamente los acuerdos objeto de los incidentes de ejecución «son actos de tramitación insertados en un procedimiento parlamentario, pero, aunque no ponen fin al mismo", considera que «pueden ser objeto idóneo de impugnación por la vía del art. 92 LOTC», ya que, a diferencia del supuesto objeto del ATC 135/2004, de 20 de abril, en este caso no estamos ante una impugnación de disposiciones autonómicas del título V LOTC, sino ante «un incidente de ejecución, que tiene por objeto verificar si los poderes públicos han respetado su deber de acatar lo resuelto por el Tribunal Constitucional (art. 87.1 LOTC)», estando el TC facultado en este procedimiento para «declarar la nulidad de cualesquiera resoluciones que contravengan las dictadas en el ejercicio de su jurisdicción, con ocasión de la ejecución de éstas (art. 92.1 LOTC), sin perjuicio de la posibilidad de adoptar cuantas otras medidas de ejecución sean necesarias».

Recuerda también la posibilidad de que el Gobierno invoque la facultad de suspensión que le confiere el art. 161.2 CE en los incidentes de ejecución de las resoluciones del TC, ya anteriormente admitida. Y, en fin, afirma, proyectando a estos incidentes la doctrina establecida en relación con los recursos de inconstitucionalidad y otros procesos constitucionales, que la falta de petición de dictamen al Consejo de Estado para su interposición no es obstáculo para su admisión a trámite (AATC 9 y 11/2020 [Pleno], de 28 de enero, FJ 2, ATC 16/2020 [Pleno], de 11 de febrero, FJ 2).

Tras traer a colación la doctrina constitucional sobre la finalidad del incidente de ejecución de las resoluciones del TC y sobre la obligación de las Mesas de las Cámaras de inadmitir a trámite aquellas iniciativas parlamentarias que de forma manifiesta incumplan el deber de acatar lo resuelto por él (AATC 9 y 11/2020, FF. JJ. 3 y 2, y ATC 16/2020, FF. JJ. 3 y 4), tres de los cinco incidentes de ejecución resueltos son estimados porque los apartados de las resoluciones o mociones objeto de estos reiteran anteriores pronunciamientos del Parlamento de Cataluña, que ya fueron declarados inconstitucionales y nulos por las SSTC 259/2015 y 98/2019 (AATC 9, 11 y 16/2020, respectivamente). En los autos se acuerda su notificación personal al presidente, a los miembros de la Mesa y al secretario general de la Cámara, advirtiéndoles de su deber de abstenerse de realizar cualesquiera actuaciones tendentes a dar cumplimiento a las resoluciones declaradas inconstitucionales y nulas, así como de su deber de impedir o paralizar cualquier iniciativa, jurídica o material, que directa o indirectamente pretenda o suponga ignorar o eludir la nulidad acordada, con 
expreso apercibimiento de las responsabilidades en las que pudieran incurrir en caso de incumplimiento de lo ordenado por el TC. Asimismo, se deduce testimonio de particulares a fin de que el ministerio fiscal proceda, en su caso, a exigir la responsabilidad penal que pudiera corresponderles al presidente y a los miembros de la Mesa al pronunciarse a favor de la admisión a trámite de las iniciativas parlamentarias e incumplir el deber de acatamiento de las resoluciones del TC.

En los otros dos incidentes de ejecución se acuerda su extinción por pérdida de objeto, al haber sido declarada en los AATC 9 y 16/2020 la nulidad de los apartados de las resoluciones objeto de aquellos (AATC 10 y 18/2020 [Pleno], de 28 de enero y 11 de febrero, respectivamente).

3. Los motivos de especial trascendencia constitucional apreciados en los recursos de amparo resueltos durante este cuatrimestre han sido los siguientes:

a) (STC 155/2009, FJ 2 a) que el recurso plantea un problema o afecta a la faceta de un derecho fundamental sobre el que no hay doctrina del TC (SSTC 2/2020 [Pleno], de 15 de enero — prisión provisional de candidato a la presidencia de una comunidad autónoma que impide a los diputados recurrentes participar en la segunda votación de la sesión de investidura al suspenderse su reanudación—; 3/2020 [Pleno], de 15 de enero, y 22/2020 [Pleno], de 13 de febrero - prisión provisional de cargo público representativo-; 4/2020 [Pleno], de 15 de enero —-denegación de permiso penitenciario a un candidato a la presidencia de una comunidad autónoma para asistir a la sesión de investidura—; 5/2020 [Pleno], de 15 de enero -medida cautelar de prisión provisional—; 6/2020 [Sala Segunda], de 27 de enero - denegación de autorización a un interno en un centro penitenciario para celebrar una entrevista periodística-; 7/2020 [Sala Segunda], de 27 de enero, y 40/2020 [Pleno], de 27 de febrero $^{6}$ — utilización de la dirección electrónica habilitada para primer emplazamiento en procesos por despido y de ejecución hipotecaria-; 9/2020 [Pleno], de 28 de enero — denegación de permiso penitenciario a un diputado para asistir a la sesión constitutiva de la Cámara y a la sesión de investidura de candidato a la presidencia de una comunidad

6 También se apreció como motivo de especial trascendencia constitucional que el recurso puede dar ocasión al TC para aclarar o cambiar su doctrina como consecuencia de cambios normativos relevantes para la configuración del derecho fundamental (STC 155/2009, FJ 2 b). 
autónoma—; 10/2020 [Pleno], de 28 de enero —recurso de amparo contra la desestimación de incidente de recusación sin haber concluido el proceso penal—; 11 y 12/2020 [Pleno], de 28 de enero, 38 y 39/2020 [Pleno], de 25 de febrero —medida cautelar de suspensión en el ejercicio de cargo público por aplicación del art. 384 bis LECrim—; 18/2020, [Sala Primera], de 10 de febrero - sanción disciplinaria a interno en un centro penitenciario por el contenido de escritos en los que formulaba peticiones y quejas a las autoridades—; 21/2020 [Pleno], de 11 de febrero — desestimación de petición de libertad de un candidato a la presidencia de una comunidad autónoma para asistir a la sesión de investidura-; 23/2020 (Pleno), de 13 de febrero — denegación de puesta en libertad y/o permiso penitenciario al recurrente para asistir como candidato a la sesión de investidura de la presidencia de una comunidad autónoma y a su participación no presencial en esta mediante videoconferencia-; 26/2020 [Sala Primera], de 24 de febrero — aplicación indebida del Reglamento (CE) núm. 804/2004 del Parlamento Europeo y del Consejo, de 21 de abril de 2004, por el que se establece un título ejecutivo europeo para créditos no impugnados_; 27/2020 [Sala Segunda] —reportaje periodístico ilustrado con una fotografía extraída de un perfil personal de Facebook abierto y accesible al público—; 28/2020 [Sala Segunda], de 24 de febrero - resoluciones judiciales que ordenan mantener en el Registro de la Propiedad la mención a delitos por los que se siguen diligencias penales en anotación registral de prohibición de disponer de una finca—; 34/2020 [Sala Segunda], de 24 de febrero — anuncio de subasta que incurre en error esencial manifiesto al calificar el bien objeto de esta—; 35/2020 [Pleno], de 25 de febrero — condena por delito de enaltecimiento del terrorismo o humillación a las víctimas por la publicación de diversos tuits—; 36/2020 [Pleno], de 25 de febrero —-denegación a un candidato de permisos penitenciarios para participar en campaña electoral en elecciones parlamentarias, de contactos adicionales con los medios de comunicación y de disponibilidad de internet más allá del régimen ordinario del establecimiento penitenciario-, y 37/2020 [Pleno], de 25 de febrero — prisión provisional de parlamentarios, siendo uno de ellos candidato a la presidencia de una comunidad autónoma, acordada antes de reanudarse la sesión de investidura para la celebración del segundo debate y votación del candidato-).

b) (STC 155/2009, FJ b) que el recurso puede dar ocasión al TC para aclarar o cambiar su doctrina como consecuencia de un proceso de 
reflexión interna (SSTC 24/2020 [Pleno], de 13 de febrero ${ }^{7}$ —inadmisión a trámite de proposición de ley por contradecir de manera palmaria y evidente la Constitución-; 42/2020 [Sala Primera], de 9 de mayo - denegación de tarjeta de residencia como familiar de un ciudadano de la Unión Europea-, y 45/2020 [Sala Segunda], de 9 de mayo — denegación de indemnización por prisión provisional en causa penal en la que el demandante ha sido absuelto-).

c) (STC 155/2009, FJ b) que el recurso puede dar ocasión al TC para aclarar o modificar su doctrina como consecuencia de cambios normativos relevantes para la configuración del contenido del derecho fundamental (SSTC 19/2020 [Sala Primera], de 10 de febrero, y 43/2020 [Sala Segunda], de 9 de mayo —utilización de la dirección electrónica habilitada para primer emplazamiento en juicio verbal por desahucio-).

d) (STC 155/2009, FJ 2 c) que la vulneración del derecho fundamental que se denuncia pudiera provenir de la ley o de otra disposición de carácter general (SSTC 8/2020 [Sala Primera], de 27 de enero - denegación de indemnización por prisión provisional en causa penal en la que el demandante ha sido absuelto-; 17/2020 [Sala Segunda], de 20 de febrero, y 33/2020 [Sala Segunda], de 24 de febrero -impugnabilidad jurisdiccional de decretos de letrados de la Administración de justicia-; 31/2020 [Sala Primera], de 24 de febrero — falta de motivación de resoluciones judiciales recaídas en procedimiento de ejecución de decretos de letrado de la Administración de justicia en reclamación de honorarios de letrado-, y 44/2020 [Sala Segunda], de 9 de mayo — denegación de indemnización por haber sufrido prisión provisional en causa penal en la que el demandante ha sido absuelto-).

e) (STC 155/2009, FJ 2 e) que la doctrina del TC sobre el derecho fundamental que se alega podría estar siendo incumplida de modo general y reiterado por la jurisdicción ordinaria o pudieran existir resoluciones judiciales contradictorias (STC 1/2020 [Pleno], de 14 de enero - aplicación en casación de una agravante y un subtipo agravado sin ofrecer a los acusados la posibilidad de alegar en su defensa-).

f) (STC 155/2009, FJ 2 f) que el órgano judicial pudiera haber incurrido en una negativa manifiesta del deber de acatamiento de la

También se apreció como motivo de especial magnitud constitucional que el asunto suscitado trasciende del caso concreto al poder tener unas consecuencias políticas generales (STC 155/2019, FJ 2g). 
doctrina del TC (STC 29/2020 [Sala Segunda], de 24 de febrero emplazamiento edictal en proceso de ejecución hipotecaria-, y 32/2020 [Sala Segunda], de 24 de febrero - requerimiento de pago a través de edictos en procedimiento de ejecución hipotecaria-).

g) (STC 155/2019, FJ 2 g) que el recurso plantea una cuestión de relevante y general repercusión social o económica (SSTC 30/2020 [Sala Primera], de 24 de febrero - falta de control judicial de cláusulas abusivas desconociendo la primacía del derecho de la Unión Europea y la jurisprudencia del TJUE—; 42/2020 [Sala Primera], de 9 de mayo - notificación y requerimiento de pago mediante edictos en procedimiento de ejecución hipotecaria-, y ATC 40/2020 [Sala Primera], de 30 de abril — prohibición de celebración de una manifestación declarado el estado de alarma para la gestión de la crisis sanitaria ocasionada por la covid-19-).

4. En relación con el requisito de la especial trascendencia constitucional, la STC 1/2020 (Pleno), de 14 de enero, reitera que «se exige del recurso y no de cada uno de los motivos en los que se fundamenta» (FJ 2). De otra parte, son cada vez más las sentencias en las que se explicita y argumenta en su fundamentación jurídica la concurrencia del motivo o motivos de especial trascendencia constitucional apreciados en la admisión del recurso, precisando, por ejemplo, la doctrina constitucional que se considera que está siendo incumplida de modo general y reiterado (STC 1/2020, FJ 2), o la cuestión novedosa que plantea el recurso (STC 4/2020 [Pleno], de 15 de enero, FJ 4), o, en fin, el concreto problema o faceta del derecho fundamental sobre el que no existe doctrina constitucional (STC 34/2020 [Sala Segunda], de 24 de febrero, FJ 2).

En la STC 32/2020 (Sala Segunda), de 24 de febrero, se sintetiza la doctrina sobre el motivo de especial trascendencia constitucional consistente en la negativa manifiesta del deber de los órganos judiciales de acatar la doctrina del TC (STC 155/2009, FJ 2 f). Para la apreciación del citado motivo es precisa la concurrencia - como se explicita en la sentencia- de los siguientes requisitos: a) el motivo no se puede identificar con «la errónea interpretación o aplicación de la jurisprudencia, incluso si fuera objetivable y verificable en el caso concreto», sino como «la voluntad manifiesta de no proceder a su aplicación; o dicho en otras palabras, a una decisión consciente de soslayarla»; b) el incumplimiento por sí solo de la doctrina del TC «no puede ser considerado como un supuesto de especial trascendencia constitucional», pero, apreciada «la existencia de una negativa manifiesta», el TC «debe conocer del recurso y aplicar su doctrina al caso concreto»; c) procede apreciar la concurrencia de esa voluntad del órgano judicial de negarse a acatar la doctrina 
del TC en los supuestos en los que el órgano judicial, aun conociendo la doctrina constitucional, por haber sido "citada y extractada en lo fundamental» por la parte, omite toda consideración sobre esta, y d) «en todo caso, la cita de la doctrina constitucional ha de ser concreta y precisa, no siendo suficiente cualquier pronunciamiento jurisprudencial que se entienda incumplido» (FJ 2).

5. Respecto al cómputo del plazo para interponer el recurso de amparo, el TC desestima en la STC 18/2020 (Sala Primera), de 10 de febrero ${ }^{8}$, la extemporaneidad aducida como óbice procesal por el abogado del Estado, al considerar que el plazo para la interposición de la demanda de amparo se interrumpe con la presentación por el demandante en el centro penitenciario en el que se encuentra interno de un escrito solicitando la designación de abogado del turno de oficio para la interposición de la demanda, de modo que, en estos casos, el dies ad quem al que hay que estar para la apreciación de la extemporaneidad o no de la demanda «no es el de la fecha de formalización del recurso de amparo», sino cuando el recurrente «solicitó la designación de letrado del turno de oficio para la interposición de la demanda de amparo» (FJ 2).

Por su parte, la interposición de un recurso de aclaración contra la resolución judicial que pone fin a la vía judicial previa «debe tener el efecto de desplazar el dies a quo» para la interposición de la demanda de amparo «desde el día siguiente al de la notificación de la resolución aclarada hasta el día siguiente al de la notificación de la resolución aclaratoria, cuando la presentación del recurso de aclaración no constituya un abuso de derecho ni una maniobra dilatoria» (STC 34/2020 [Sala Segunda], de 24 de febrero', FJ 2).

6. La falta de agotamiento de la vía judicial previa en relación con alguno de los motivos de los recursos de amparo acumulados que resolvió la STC 1/2020 (Pleno), de 14 de enero, fue desestimada como óbice procesal por el TC, pues, a pesar de que aquellas vulneraciones no habían sido denunciadas por algunos de los demandantes de amparo en el incidente de nulidad de actuaciones que promovieron contra la sentencia condenatoria, se trata de «un motivo de alcance general para todos los condenados, habiendo sido suscitado en diversos incidentes de nulidad de actuaciones por otros condenados y resuelto por el órgano judicial de casación", de modo que no puede descartarse ex art. 903 LECrim que su eventual estimación hubiera aprovechado a todos los recurrentes (FJ 3).

\footnotetext{
8 Véanse infra pp. 256-257.

$9 \quad$ Véase infra p. 263.
} 
Por su parte, la STC 8/2020 (Sala Primera), de 27 de enero, desestima también la denunciada falta de agotamiento de la vía judicial previa al haberle sido inadmitido al demandante un recurso de casación por no haber fundamentado debidamente la concurrencia de alguno o algunos de los supuestos que permiten apreciar el interés casacional objetivo y por carecer, además, el recurso de interés casacional para la formación de jurisprudencia. El TC, en aplicación de la doctrina de la STC 121/2019, de 28 de octubre (FJ 2$)^{10}$, considera que en este caso no puede entenderse incumplido el referido requisito procesal, pues la sala de instancia tuvo por preparado el recurso de casación al apreciar que cumplía el plazo y los requisitos procesales, y el Tribunal Supremo, por su parte, consideró que el escrito de preparación tenía una justificación insuficiente y apreció, además, una segunda causa de inadmisión del recurso - carecer de interés casacional objetivo para la formación de jurisprudencia- En estas circunstancias —entiende el TC - «no es posible estimar que la inadmisión del recurso de casación obedeciera a un defecto formal manifiesto e incontrovertible», es decir, que «fuera imputable de forma clara e inequívoca a la falta de diligencia de la parte», por lo que concluye que debe entenderse debidamente agotada la vía judicial previa (FJ 2).

Asimismo, en la STC 40/2020 (Pleno), de 27 de febrero, se desestima la prematuridad del recurso de amparo por haberse interpuesto la demanda sin esperar a la finalización del procedimiento hipotecario, que legalmente no puede tenerse por finalizado hasta que el letrado de la Administración de justicia decrete la «completa satisfacción» del ejecutante (art. 570 LEC). Para el TC, en estos casos, "condicionar la interposición de la demanda de amparo a este hecho, genera una dilación injustificada que se traduciría en un gravamen adicional o en la intensificación de la lesión constitucional que se denuncia». El TC, por lo tanto, aplica el mismo criterio que viene observando en «aquellos recursos de amparo promovidos contra resoluciones dictadas en procesos de ejecución donde, como aquí, se había impedido conocer de los motivos de oposición a la ejecución presentados por la parte, sin tener para ello que esperar a la terminación de estos procesos» (FJ 2).

Por el contrario, en la STC 12/2020 (Pleno), de 28 de enero, se inadmite por prematuro el recurso de amparo promovido contra la decisión del magistrado instructor de comunicar a la Cámara la suspensión del recurrente en el ejercicio del cargo de parlamentario en aplicación del art. 384 bis LECrim, pues cuando se interpuso la demanda de amparo se encontraban

10 Reseñada en Revista Española de Derecho Constitucional, núm. 118 (2020), pp. 230-231. 
pendientes de resolución los recursos de reforma y subsidiario de apelación promovidos contra aquella decisión judicial. En definitiva, como se dice en la sentencia, que contiene una completa síntesis de la doctrina constitucional sobre la prematuridad del recurso de amparo y la coexistencia de la vía judicial previa y la del amparo, "por haber simultaneado el demandante de amparo el recurso de amparo con otros planteados en la vía judicial previa en la fecha de interposición de la demanda de amparo». El TC desestima el alegato del demandante sobre la demora de los órganos judiciales en resolver los recursos de reforma y apelación, pues recuerda que «la simple demora en la resolución de los recursos en la vía judicial no autoriza a prescindir de un aspecto medular del recurso de amparo, a saber, su naturaleza subsidiaria».

7. Durante el período que abarca esta crónica se dan dictado tres sentencias en materia de legitimación del recurso de amparo.

a) En la STC 24/2020 (Pleno), de 13 de febrero, el TC inadmite el recurso de amparo promovido contra la decisión de la Mesa del Congreso de los Diputados de inadmitir a trámite una proposición de ley "para el fomento de la transparencia económico-presupuestaria del Rey y de la Casa Real», por falta de legitimación de los cuatro diputados recurrentes, al carecer de la facultad para presentar una proposición de ley y no ostentar la representación del grupo parlamentario autor de la iniciativa.

Proyectando una reiterada doctrina constitucional sobre la necesidad de «una interpretación integradora» de las previsiones de los arts. 162.1.b) CE y 46 LOTC a los recursos de amparo parlamentarios en relación con las facultades de iniciativa o propuestas conferidas a una agrupación ocasional de parlamentarios o a los grupos en los que se integran, el TC ha venido entendiendo, cuando se trate de una agrupación ocasional de parlamentarios, que, «si no existe identidad entre los parlamentarios demandantes de amparo y la agrupación de parlamentarios autora de la iniciativa o propuesta, aquéllos carecen de legitimación para interponer recurso de amparo contra los acuerdos de las cámaras que inadmitan la iniciativa o propuesta en cuestión» (STC 98/2009, de 27 de abril) ${ }^{11}$, y, cuando se trata de iniciativas de grupos parlamentarios, que «los parlamentarios que comparecen en el

11 Reseñada en Revista Española de Derecho Constitucional, núm. 86 (2009), pp. 272-273. 
recurso de amparo a título individual sin ostentar la representación del grupo parlamentario o de sus miembros, salvo que se personen todos sus componentes, carecen también de legitimación para arrogarse la defensa de los derechos y facultades del grupo al que pertenecen» (STC 168/2012, de 1 de octubre) ${ }^{12}$.

En el supuesto objeto de la sentencia ahora reseñada, la proposición de ley inadmitida a trámite había sido presentada por el grupo parlamentario mixto con la firma de su portavoz, si bien en el escrito de presentación aparecía también la firma de los cuatro diputados recurrentes en amparo haciendo constar su condición de electos por la formación política Compromís, integrados en el citado grupo parlamentario. El TC entiende, como así lo hizo la Mesa del Congreso de los Diputados, que «se trata de una proposición de ley del grupo parlamentario mixto", siendo irrelevante a los efectos de su autoría que el grupo parlamentario "decidiese presentarla a "instancias" de uno de sus miembros y de que conste en el escrito de presentación, además de la firma del portavoz del grupo parlamentario, la de los cuatro diputados recurrentes en amparo».

Pues bien, el TC concluye que los cuatro diputados recurrentes en amparo carecen de legitimación ex arts. 162.1.b) CE y 46.1.a) LOTC para recurrir en amparo el acuerdo de inadmisión de la Mesa del Congreso de los Diputados, al «no ser titulares individual o en el número en el que han comparecido en este proceso de la facultad de presentar una proposición de ley ante el Congreso de los Diputados» (art. 126.1 RCD), «ni ostentar la representación del grupo parlamentario autor de la iniciativa o la de los diputados que lo integran».

b) Por su parte, el TC, en la STC 2/2020 (Pleno), de 15 de enero, niega falta de legitimación ad procesum a los diputados del Parlamento de Cataluña que promovieron recurso de amparo contra el auto del magistrado instructor designado por la Sala Segunda del Tribunal Supremo en la causa penal dimanante del proceso secesionista por el que se acuerda la prisión provisional del candidato a la presidencia de la Generalitat, circunstancia que determinó la suspensión de la reanudación de la sesión de investidura para la celebración del segundo debate y votación.

Aunque reconoce a los recurrentes legitimación ad causam, ya que por la resolución judicial impugnada han visto mermadas sus facultades

12 Reseñada en Revista Española de Derecho Constitucional, núm. 97 (2013), p. 258. 
como miembros de la Cámara a participar en la sesión de investidura, el TC les niega legitimación ad procesum (art. 46.1.b, en relación con el art. 44.1.a y c, ambos LOTC), al no haber preservado el carácter subsidiario del recurso de amparo, lo que determina su inadmisión a trámite.

En efecto, el TC reprocha a los recurrentes no haber tratado de "personarse en el procedimiento, a efectos de defender los derechos que podían resultar comprometidos, ni tampoco comparecer ante el juez para denunciar la injerencia en sus derechos de participación política (art. 23.2 CE), al objeto de que el órgano judicial pudiese ponderar dicha circunstancia». También les reprocha no haber impugnado la resolución judicial recurrida en amparo, habiendo acudido ante el TC «sin tratar de interponer el correspondiente recurso de apelación o, al menos, adherirse al formalizado" por el candidato a la presidencia de la Generalitat, cuya «eventual estimación habría conllevado, en todo caso, la libertad del candidato a la presidencia, circunstancia que podría desbloquear la investidura ${ }^{13}$.

c) En fin, en la STC 39/2020 (Pleno), de 25 de febrero, se niega legitimación a los recurrentes en amparo para impugnar las resoluciones judiciales por las que se comunicó al Parlamento de Cataluña la suspensión en el ejercicio de sus cargos públicos de seis miembros de la Cámara al ser procesados por un delito de rebelión y encontrarse en prisión provisional (art. 384 bis LECrim).

El TC entiende que los ciudadanos recurrentes en amparo carecen de interés legítimo ex arts. 162.1 CE y 46 LOTC para impugnar aquellas resoluciones judiciales, pues, en relación con el derecho fundamental al ejercicio del cargo público representativo (art. 23.2 CE) que invocan, no se encuentran «en una situación jurídico-material identificable con un interés propio, cualificado o específico», que ha de ser «distinta de la disconformidad o el descontento que pueda sentir cualquier ciudadano ante lo que él percibe como una infracción objetiva de un derecho de rango fundamental». Por el contrario, estima que los recurrentes se hallan en «una relación puramente genérica con el derecho fundamental que, de ser reconocida como

13 Con base en idénticas razones, en la STC 7/2020 (Pleno), de 11 de febrero, se inadmite a trámite el recurso de amparo interpuesto por diputados del Parlamento de Cataluña contra la resolución judicial que desestimó la petición de libertad de un miembro de la Cámara que se encontraba en prisión provisional para asistir a la sesión de investidura como candidato a la presidencia de la Generalitat. 
suficiente para habilitar el acceso al recurso de amparo», supondría reconocer «una acción popular o pública en defensa de los derechos fundamentales». En este sentido, el TC concluye que el hecho de que los recurrentes hayan participado como electores en las elecciones al Parlamento de Cataluña no cualifica su posición jurídica frente a cualquier otro ciudadano que sea titular del derecho de sufragio en dichas elecciones, «siendo, además, la representación política asumida por los que resultaron entonces elegidos la de toda la ciudadanía de Cataluña y no solamente la de aquellos que afirman haberles confiado su voto».

8. El ATC 17/2020 (Pleno), de 11 de febrero, desestima la recusación de un magistrado del TC planteada por el Gobierno de la Generalitat de Cataluña en relación con diversos recursos de inconstitucionalidad y conflictos de competencias contra leyes y normas de la Generalitat.

Se recuerda en el auto la doctrina constitucional sobre la garantía y el deber de imparcialidad de los magistrados constitucionales, resaltando la modulación con que deben aplicarse las causas de recusación en aquellos procesos constitucionales que tienen por objeto un juicio abstracto sobre la constitucionalidad de las normas impugnadas, así como la doctrina elaborada con ocasión de la recusación basada en el contenido de un voto particular que puedan emitir los magistrados constitucionales (FJ 2).

El TC descarta que en el caso enjuiciado concurran las causas de recusación invocadas por el Gobierno de la Generalitat, pues aquellas se fundan en el contenido del voto particular formulado por el magistrado recusado a la STC 132/2019, de 13 de noviembre, que resolvió el recurso de inconstitucionalidad contra determinados preceptos del Código Civil de Cataluña. El TC reitera que "la facultad de emitir votos particulares es consustancial a la función desempeñada por los magistrados del Tribunal y que no cabe admitir, en principio, una recusación basada en afirmaciones y posicionamientos que se expresan en ellos».

Tras este pronunciamiento genérico desestimatorio de la recusación, el TC rechaza las concretas causas de recusación aducidas. Por lo que se refiere a la relativa a la supuesta «amistad íntima o enemistad manifiesta con cualquiera de las partes» (art. 219.9 LOPJ), concluye que dado el carácter personalísimo de esta casusa «no es posible admitir, ni lógica ni jurídicamente, que el magistrado recusado [...] mantenga [...] una relación de amistad con "los catalanes, la Generalitat de Cataluña, su Gobierno o Parlamento"». Y respecto a un posible "interés directo o indirecto en el objeto del pleito", entiende que «no puede admitirse que la opinión vertida en el ejercicio de las funciones 
que constitucionalmente corresponden a un magistrado constitucional en un asunto ya resuelto pueda revelar un interés en el sentido de esta causa de recusación», es decir, que del resultado del proceso se pueda «derivar un potencial provecho para el magistrado recusado, sin que sea admisible reconducir la tacha al plano exclusivamente de la discrepancia en la interpretación de los preceptos constitucionales» $(\mathrm{FJ} 3)^{14}$.

Por su parte, con cita de las precedentes SSTC 129, 130 y 131/2018 (Pleno), de 12 de diciembre ${ }^{15}, 20 / 2019$ (Pleno), de 12 de febrero, y 38 y 39/2019 (Pleno), de 26 de marzo $^{16}$, en las SSTC 10/2020 (Pleno), de 28 de enero, 23/2020 (Pleno), de 13 de febrero ${ }^{17}$, 36 y 38/2020 (Pleno), de 25 de febrero $^{18}$, se inadmiten por prematuros los motivos de amparo aducidos contra las resoluciones judiciales que, a su vez, inadmitieron a limine o desestimaron incidentes de recusación promovidos contra el magistrado instructor o miembros de la Sala de lo Penal del Tribunal Supremo en la causa penal seguida por el proceso secesionista en Cataluña.

La cuestión nuclear examinada gira en torno a la posibilidad de impugnar en amparo resoluciones interlocutorias dictadas en un proceso penal en curso. En aplicación de una reiterada doctrina constitucional, se recuerda en las sentencias ahora reseñadas que las resoluciones judiciales que ponen término a un incidente de recusación no suponen el agotamiento de la vía judicial previa, ya que en la fase preliminar del juicio oral, tanto en el procedimiento abreviado como en el proceso ordinario por delito, es posible hacer valer y obtener a través de las cuestiones de previo pronunciamiento la reparación de supuestas vulneraciones de derechos fundamentales que se aleguen por las partes. Esta falta de agotamiento de la vía judicial previa al recurso de amparo se aprecia no solo en relación con el pronunciamiento de fondo sobre la recusación formulada, sino que se extiende también a las supuestas vulneraciones de derechos procesales que se hubieran podido producir durante la tramitación del incidente de recusación ${ }^{19}$.

14 Con remisión a los razonamientos contenidos en este auto, en el ATC 34/2020 (Pleno), de 25 de febrero, se desestima la recusación formulada por el Gobierno de la Generalitat de Cataluńa contra el mismo magistrado en un recurso de inconstitucionalidad.

15 Reseñadas en Revista Española de Derecho Constitucional, núm. 115 (2019), pp. 261-263.

16 Reseñadas en Revista Española de Derecho Constitucional, núm. 116 (2019), pp. 229-231.

17 Véase infra p. 264.

18 Véase infra p. 265.

19 Juan Carlos Duque Villanueva. 


\section{FUENTES DEL DERECHO}

1. La STC 13/2020 (Pleno), de 28 de enero ${ }^{20}$, que resuelve el recurso de inconstitucionalidad interpuesto por el presidente del Gobierno contra determinados preceptos de la Ley de las Cortes de Aragón 8/2018, de 28 de junio, de actualización de los derechos históricos de Aragón, aplica la doctrina sentada en la STC 158/2019 (Pleno), de 12 de diciembre, que resolvió el recurso de inconstitucionalidad promovido por más de cincuenta diputados contra dicha ley autonómica, y que fue reseñada en la crónica del cuatrimestre precedente ${ }^{21}$.

Conforme a reiterada doctrina constitucional, la coincidencia parcial del objeto entre un recurso y otro y la declaración por la STC 158/2019 de la inconstitucionalidad y nulidad de varios preceptos de dicha ley impugnados en ambos recursos, con la consiguiente expulsión del ordenamiento jurídico de esos preceptos, determinan la pérdida sobrevenida de objeto del recurso del presidente del Gobierno en lo que a ellos respecta. Por tanto, este recurso queda circunscrito a las normas de la ley autonómica impugnadas por el presidente del Gobierno que no han sido anuladas por la STC 158/2019. Acotado así el objeto del recurso de inconstitucionalidad, la STC 13/2020 proyecta al caso la doctrina sentada en la STC 158/2019, reiterando, por tanto, la conclusión de que es contrario a lo previsto en la disposición adicional primera $\mathrm{CE}$ hacer de los «derechos históricos» el fundamento del poder autonómico o el origen de este o la finalidad de su ejercicio (STC 158/2019, FJ 5), y estima parcialmente el recurso.

En particular, la STC 13/2020 recuerda que la reserva estatutaria (art. 147.2 CE) no impide al legislador aragonés, en ejercicio de la competencia de organización de sus instituciones de autogobierno que le reconocen el art. 148.1.1 CE y el art. 71.1 de su Estatuto de Autonomía, desarrollar las previsiones estatutarias, siempre que respeten su contenido. De ello se infiere que el precepto de la Ley de las Cortes de Aragón 8/2018 que dispone que la ciudad de Zaragoza es la capital de Aragón y la sede permanente de las instituciones autonómicas (sin perjuicio de que puedan reunirse en otros lugares de su territorio, con arreglo a las leyes), y prevé para ella un régimen especial aprobado por ley autonómica, coincide con las previsiones del Estatuto de Autonomía de Aragón. Otro tanto sucede con el precepto legal que regula la precedencia en los actos oficiales entre las autoridades e instituciones aragonesas, con el que regula las funciones del Justicia de Aragón y con el que regula las funciones de la Diputación General de Aragón; de manera

20 Véase infra pp. 248-249..

21 Reseñada en Revista Española de Derecho Constitucional, núm. 118 (2020), pp. 220, $233-235$ y $253-254$. 
que la impugnación de estos preceptos se desestima. Por el contrario, se estima la impugnación del precepto legal que atribuye al presidente de Aragón la competencia para convocar el referéndum de ratificación de la reforma estatutaria: esa competencia se atribuye en el Estatuto de Autonomía al Gobierno de Aragón y no al presidente, por lo que el precepto contradice el Estatuto, lo que determina que sea declarado inconstitucional y nulo (STC 13/2020, FJ 3).

Desestima también la STC 13/2020 la impugnación del precepto legal que se refiere a la Cámara de Cuentas de Aragón como órgano de fiscalización externa, fundada en que el legislador autonómico omite toda alusión al Tribunal de Cuentas y a las competencias que le atribuyen el art. $136 \mathrm{CE}$ y la Ley Orgánica 2/1982, de 12 de mayo, como supremo órgano fiscalizador económico-financiero del Estado y del sector público. Recuerda el TC que el silencio de una ley autonómica sobre la aplicación del bloque de la constitucionalidad no merece tacha, puesto que este se rige por su propia primacía, con independencia de su mención expresa en la legislación estatal o autonómica, según reiterada doctrina; y ello con independencia de que tanto el Estatuto de Autonomía de Aragón como la Ley 11/2009, de 30 de diciembre, de la Cámara de Cuentas de Aragón, disponen que las funciones (fiscalizadoras) de este órgano de control externo se entienden sin perjuicio de las legalmente atribuidas al Tribunal de Cuentas (STC 13/2020, FJ 3).

2. Acerca de los límites que el art. 86.1 CE impone a la utilización del decreto ley por el Gobierno se pronuncia en el cuatrimestre reseńado la STC 14/2020 (Pleno), de 28 de enero, que reitera la conocida doctrina constitucional al respecto.

La STC 14/2020 estima parcialmente el recurso de inconstitucionalidad interpuesto por 102 diputados del Grupo Parlamentario Popular del Congreso de los Diputados contra el Real Decreto Ley 7/2019, de 1 de marzo, de medidas urgentes en materia de vivienda y alquiler. Declara la inconstitucionalidad y nulidad, por insuficiente justificación del presupuesto habilitante o por ausencia de la necesaria conexión de sentido, de los preceptos impugnados del Real Decreto Ley 7/2019 que introducen medidas para promover la oferta de vivienda en alquiler e inciden sobre los convenios administrativos en materia de infraestructuras.

Tras recordar la reiterada doctrina sobre el concepto de «extraordinaria y urgente necesidad» que emplea el art. 86.1 CE y el control que de este presupuesto habilitante del decreto ley corresponde al TC llevar a cabo, la STC 14/2020 aborda la primera queja de los diputados recurrentes, que consideran que el Real Decreto Ley 7/2019 no contiene verdaderamente una definición explícita y razonada de la situación de extraordinaria y urgente necesidad que 
legitime el empleo de este instrumento normativo excepcional. Se exponen las razones ofrecidas por el Gobierno sobre el presupuesto habilitante en la exposición de motivos del decreto ley impugnado, así como las que resultan de la intervención del ministro de Fomento en defensa del Real Decreto Ley 7/2019 en el debate de convalidación de este ante la Diputación Permanente del Congreso de los Diputados y las contenidas en la memoria del análisis de impacto normativo aportada por el Gobierno en su escrito de alegaciones en el recurso de inconstitucionalidad. De ello resulta que el Gobierno quiere atender con el decreto ley impugnado a una situación de un grupo «numeroso y delimitado objetivamente» de familias que carecen de vivienda en propiedad y destinan un porcentaje de ingresos elevado (más del $40 \%$ ) al pago del alquiler, sin oferta alternativa de vivienda suficiente o adecuada, debido a la ausencia de parques públicos de viviendas y al incremento de los precios consecuencia de las ventajas que para los propietarios genera el alquiler turístico, especialmente en determinadas zonas del territorio nacional, y que se ven por ello amenazadas de desahucio, a lo que se añade el problema de las deficiencias en materia de accesibilidad en muchas viviendas, agravado por el progresivo envejecimiento de la población.

El TC considera que la situación descrita por el Gobierno se mantiene dentro de los márgenes de apreciación que deben reconocérsele para hacer uso del decreto ley; se trata de una situación acreditada de manera suficiente y que reúne las características del art. 86.1 CE que legitiman al Gobierno para revertirla o corregirla con urgencia, más rápidamente que mediante la aprobación de una ley formal en el Parlamento. En consecuencia, se descarta la queja relativa a que no se justifica el presupuesto habilitante del Real Decreto Ley 7/2019 considerado en su conjunto (STC 14/2020, FJ 4).

Descartado este primer motivo de impugnación del Real Decreto Ley 7/2019, el TC aborda el examen de las impugnaciones que los recurrentes dirigen a determinados preceptos de esta norma excepcional, analizando si concurre o no el requisito de la conexión de sentido entre la situación de extraordinaria y urgente necesidad definida y las concretas medidas adoptadas en el decreto ley. Este análisis de detalle conduce a la estimación parcial del recurso, declarando la inconstitucionalidad y nulidad de las disposiciones adicionales primera y tercera del Real Decreto Ley 7/2019, que introducen, respectivamente, medidas para promover la oferta de vivienda en alquiler e inciden sobre los convenios administrativos en materia de infraestructuras.

Por lo que atañe a las medidas para promover la oferta de vivienda en alquiler, que prevé la disposición adicional primera, el TC aprecia que el Gobierno no ha justificado la necesidad de acudir a una norma con rango de ley para adoptar esas medidas. No se acredita, en suma, «que ninguna de esas 
actuaciones precise una norma con rango de ley (el vigente plan estatal de vivienda se contiene en el Real Decreto 106/2018, de 9 de marzo), ni desde luego la necesita la labor de estudio o planificación de reformas por la administración, a la que se dirige la disposición, que es de eficacia puramente interna o doméstica» (STC 14/2020, FJ 5).

El TC recuerda su doctrina conforme a la cual no existen en la Constitución de 1978 reservas de reglamento, lo cual implica que a la ley (y, por tanto, al decreto ley, siempre que se cumplan los requisitos del art. 86.1 CE) no le está vedada la regulación de materias atribuidas anteriormente al poder reglamentario. Profundizando en esa doctrina, la STC 14/2020, FJ 5, declara que la utilización del decreto ley solamente será constitucionalmente legítima si el reglamento no permite dar la respuesta urgente a la situación que según el Gobierno es preciso resolver. Es decir, si de lo que se trata es de utilizar un decreto ley para ordenar una materia que antes era regulada por normas reglamentarias, la justificación del empleo del decreto ley impone al Gobierno la necesidad de razonar por qué esa regulación requería precisamente la elevación del rango normativo en el momento en que se aprobó el decreto ley en cuestión. Como esa justificación no existe en este caso, el TC concluye que la disposición adicional primera del Real Decreto Ley 7/2019 no cumple los requisitos del art. 86.1 CE para su aprobación mediante decreto ley, por lo que la declara inconstitucional y nula.

Asimismo declara inconstitucional y nula la disposición adicional tercera del Real Decreto Ley 7/2019, que establece que los convenios administrativos en materia de infraestructuras de transporte terrestre, aéreo y marítimo tendrán la duración que corresponda al programa de ejecución o financiación de estas infraestructuras, que deberá incorporarse como anexo a la memoria justificativa del convenio, y cuyo plazo inicial no podrá superar los diez años, pudiendo las partes acordar su prórroga, antes de la conclusión del plazo, por un período de hasta siete años adicionales. La STC 14/2020, FJ 5, aprecia que esta regulación no guarda la necesaria relación de conexión de sentido con la situación de extraordinaria y urgente necesidad previamente definida, por lo que no se justifica el empleo del decreto ley en este caso $^{22}$.

\section{ORGANIZACIÓN TERRITORIAL DEL ESTADO}

En el período que examinar se ha producido, coincidiendo con la crisis de la covid-19, una evidente disminución en el número de resoluciones dictadas

22 Herminio Losada González 
por el TC. En lo que se refiere a las resoluciones competenciales, cabe destacar las siguientes:

1. La STC 16/2020 (Pleno), de 28 de enero ${ }^{23}$, resuelve el recurso de inconstitucionalidad interpuesto por el presidente del Gobierno contra la disposición adicional decimoséptima de la Ley 14/2018, de 26 de diciembre, de Presupuestos Generales de la Comunidad Autónoma de la Región de Murcia para el año 2019.

El objeto del recurso de inconstitucionalidad es un precepto autonómico que establece la recuperación en el ámbito del sector público de los conceptos retributivos dejados de percibir correspondientes al ajuste retributivo de los ejercicios 2013 y 2014.

El recurso es resuelto por el TC en menos de cuatro meses desde su interposición. Los plazos tan breves en los que está resolviendo el TC en los últimos tiempos pueden, indudablemente, ser un importante desincentivo para un comportamiento común en el pasado como fue el de que los representantes políticos de los distintos niveles territoriales prefiriesen acudir a la jurisdicción constitucional confiando en que su pronunciamiento se realizase muchos años después.

La sentencia examina un supuesto de inconstitucionalidad mediata en la que el parámetro de contraste de la norma autonómica es el art. 23 del Real Decreto Ley 24/2018, de 21 de diciembre, por el que se aprueban medidas urgentes en materia de retribuciones en el ámbito del sector público.

La disposición adicional decimoséptima de la norma autonómica impugnada regula la recuperación en el ejercicio 2019 de los conceptos retributivos dejados de percibir en el ámbito del sector público correspondientes a diciembre de 2013 (se suprimió una paga adicional del complemento específico) y establece el calendario de recuperación para la de junio de 2014.

La sentencia concluye que la norma estatal de contraste, art. 23 del Real Decreto Ley 24/2018, es formal y materialmente básica, pues se encuentra recogida en una norma con rango de ley que se caracteriza como tal, y se fundamenta tanto en el art. 149.1.13 CE, en tanto que limita la capacidad de las Administraciones y el resto de las entidades que integran el sector público de recuperar determinados importes retributivos que, por minoración o falta de aplicación, sus empleados públicos no percibieron en ejercicios anteriores, como en el art. 156.1 CE, ya que se relaciona con la responsabilidad del Estado de garantizar el equilibrio económico general (art. 40.1 CE), así como, específicamente, con el principio constitucional de estabilidad presupuestaria

23 Véanse infra pp. 224-225. 
(art. 135 CE) y el cumplimiento de los objetivos de déficit y de deuda y la regla de gasto que se han establecido para su consecución.

Así, para el TC la regla contenida en el apartado tercero del art. 23 del Real Decreto Ley 24/2018, que supedita la recuperación de las retribuciones de los empleados del sector público minoradas en ejercicios anteriores a que la correspondiente Administración o entidad del sector público cumpla los objetivos de déficit y deuda, así como la regla de gasto, en los términos que resultan de los apartados tercero y cuarto del art. 17 de la Ley Orgánica 2/2012, de 27 de abril, de estabilidad presupuestaria y sostenibilidad financiera, debe ser considerada materialmente básica.

Sentado el carácter básico de la norma estatal invocada por el abogado del Estado, la sentencia examina si la norma autonómica incurre en insalvable contradicción con aquella.

Para la sentencia es evidente que existe una contradicción insalvable entre ambos preceptos, pues la norma autonómica se limita a ordenar la recuperación de los conceptos retributivos dejados de percibir en 2013 y 2014, omitiendo los criterios a los que expresamente se refiere la norma estatal de contraste, $y$, con ello, infringiendo el carácter condicionado de la posibilidad de recuperación que esta última contempla, porque ha quedado acreditado, y no se ha controvertido, que las condiciones que la norma básica impone en relación con el cumplimiento de los objetivos de déficit y de deuda y la regla de gasto no se cumplían en el caso de la comunidad autónoma de la Región de Murcia.

La sentencia estima íntegramente el recurso de inconstitucionalidad. La estimación íntegra del recurso antes del transcurso del plazo de cinco meses hace innecesario que el TC se pronuncie sobre el levantamiento o mantenimiento de la suspensión, tal como obliga el art. 161.2 CE.

No obstante la estimación integra del recurso, la sentencia modula los efectos de la nulidad en relación con el apartado 1 del precepto impugnado, pues este ya hizo efectiva en la nómina del mes de febrero de 2019 la recuperación del $75 \%$ de los importes de los conceptos retributivos dejados de percibir correspondientes al ejercicio 2013 (el $25 \%$ restante ya fue devuelto en el ejercicio anterior). Así, puesto que la recuperación se produjo antes de que el Estado impugnase la norma y pudiera solicitar su suspensión ex art. 161.2 $\mathrm{CE}$, los efectos de la declaración de inconstitucionalidad son puramente declarativos.

En efecto, en este caso la norma presupuestaria autonómica hizo efectiva tal recuperación en dos meses desde que se dictó, por lo que el TC, para evitar que los trabajadores públicos tengan que devolver las cantidades ilegalmente percibidas, limita la declaración de inconstitucionalidad y nulidad del apartado 
primero al establecer que no afectará a las situaciones jurídicas consolidadas, debiéndose considerar como tales las establecidas mediante actuaciones administrativas firmes o las que, en la vía judicial, hayan sido decididas mediante sentencia con fuerza de cosa juzgada (art. 40.1 LOTC) (FJ 6).

Distinta suerte corre el apartado 2 del precepto impugnado, que preveía la recuperación de aquellos importes dejados de percibir correspondientes a 2014, durante los ejercicios 2020 y 2021, puesto que dicho apartado, declarado inconstitucional y nulo, no ha podido producir efecto alguno en virtud de la suspensión acordada en su día como consecuencia de la invocación expresa del art. 161.2 CE que realizó el presidente del Gobierno al promover el recurso de inconstitucionalidad, de modo que la sentencia no modula los efectos de la declaración de inconstitucionalidad y nulidad con la consecuencia de que los trabajadores públicos no pueden recuperar, de momento, aquellos importes correspondientes a 2014 por el hecho de que la Región de Murcia no cumple con los criterios de déficit, deuda y regla de gasto.

La representación jurídica de la comunidad autónoma plantea tres cuestiones previas que tienen cierto interés:

a) La primera es un óbice procesal de extemporaneidad y tiene que ver con el hecho de que, según el representante autonómico, no hubo negociación propiamente dicha respecto de la disposición adicional decimoséptima (a diferencia de otros preceptos objeto de controversia en los que se llegó a un acuerdo), desvirtuándose, por tanto, según el representante autonómico, el ejercicio de la facultad negociadora que dispone el art. 33.2 LOTC. Para tratar de demostrar que no hubo negociación señala el representante autonómico que en el documento final de la comisión bilateral no se recoge expresamente el desacuerdo en relación con el precepto impugnado, sin que se tuviera noticia alguna al respecto, afirma el representante autonómico, hasta la interposición del recurso de inconstitucionalidad.

En relación con este primer motivo, realiza el representante autonómico una afirmación que podría justificar una afirmación en contrario por parte del Estado, pues el hecho de que en el documento final de la comisión bilateral no se recogiese ninguna referencia en relación con el precepto impugnado, y más concretamente una referencia expresa a haber llegado a algún acuerdo, supone precisamente que el desacuerdo que justificó la apertura del procedimiento negociador subsistía. Normalmente en los documentos finales de las comisiones bilaterales se plasman los acuerdos y no los desacuerdos. 
Lo cierto es que la afirmación del representante autonómico de que no hubo negociación propiamente dicha en relación con tal precepto es de imposible constatación jurídica, pues no se levanta acta de las reuniones de las comisiones bilaterales, precisamente para permitir una mayor libertad en el procedimiento de negociación. Es cierto que, frente a lo afirmado, cabe constatar que concretamente en la referida reunión de la comisión bilateral sí se verificó la existencia de un desacuerdo en relación con el precepto finalmente impugnado. Sea como fuere, el TC rechaza el óbice planteado y recuerda que, según constante jurisprudencia, cumplidos los requisitos del art. 33.2 LOTC, como aquí se han cumplido, la admisión del recurso resulta obligada.

En efecto, recuerda la sentencia que el apartado segundo del art. 33.2 LOTC vincula la ampliación a nueve meses del plazo de interposición del recurso de inconstitucionalidad como excepción al plazo ordinario de tres meses, únicamente al cumplimiento de tres requisitos, que están contemplados en las letras a), b) y c) del citado apartado y que son los siguientes: la reunión de la comisión bilateral de cooperación entre la Administración General del Estado y la respectiva comunidad autónoma, a iniciativa de cualquiera de las dos Administraciones; la adopción en el seno de dicha comisión bilateral del acuerdo sobre iniciación de negociaciones para resolver las discrepancias, y la comunicación al TC de dicho acuerdo dentro del plazo de tres meses siguientes a la publicación de la ley, disposición o acto con fuerza de ley, así como la inserción del acuerdo en el Boletín Oficial del Estado y el diario oficial de la comunidad autónoma correspondiente.

Para el TC estos tres requisitos han sido debidamente cumplidos en este proceso, por lo que rechaza el óbice procesal planteado.

b) El letrado autonómico aduce un segundo motivo por el que la actuación del Estado resultaría desleal respecto a la comunidad autónoma de la Región de Murcia: no haber seguido una línea de actuación coherente y uniforme, creando una legítima confianza en dicha comunidad autónoma respecto a la conformidad estatal con las disposiciones legales autonómicas, pues ya en la Ley de Presupuestos de 2018 se contemplaba el abono del $25 \%$ de los importes dejados de percibir de la paga extraordinaria de diciembre de 2013 sin que el Estado recurriese la cuestión.

Para el representante autonómico es cuando la comunidad en la Ley de Presupuestos de 2019 prevé la recuperación del restante 75\% de los importes dejados de percibir de la paga extraordinaria de diciembre de 
2013 y de la de 2014 cuando el Estado los cuestiona. En suma, la Asamblea regional aprobó la Ley de Presupuestos para 2019, incluyendo la disposición adicional objeto del recurso de inconstitucionalidad sobre la base de que lo establecido el ańo anterior no fue recurrido.

La sentencia rechaza la alegación autonómica recordando que cualquier consideración sobre la falta de impugnación de disposiciones o actuaciones previas de contenido idéntico o similar al del objeto del proceso resulta completamente irrelevante en el ejercicio de la jurisdicción del TC. El TC recuerda igualmente que la indisponibilidad de las competencias desautoriza cualquier alegato asentado sobre la idea de aquiescencia por no haberse planteado recurso frente a preceptos similares anteriores.

Ciertamente, cabe señalar que entre la Ley de Presupuestos de 2018 y la de 2019 hubo un cambio de Gobierno en el Estado que puede justificar una forma distinta de abordar los conflictos competenciales en los distintos ańos presupuestarios.

c) Por último, a juicio del letrado autonómico, se habría producido la quiebra del principio de lealtad institucional y del principio de irretroactividad de disposiciones sancionadoras no favorables o restrictivas de derechos individuales, y de los principios de seguridad jurídica y de interdicción de la arbitrariedad de los poderes públicos (art. 9.3 $\mathrm{CE}$ ), por el hecho de que la norma estatal de contraste se publicó en el Boletín Oficial del Estado el 27 de diciembre de 2018, un día después de la aprobación de la norma autonómica impugnada.

La sentencia rechaza la alegación planteada y recuerda que, de acuerdo con la doctrina del ius superveniens, las controversias competenciales deben resolverse teniendo en cuenta el marco jurídico vigente en el momento de su resolución. Lo cual significa que no existe obstáculo jurídico alguno, tampoco desde la óptica de la lealtad institucional, para que las normas que conforman el parámetro de control sean posteriores en el tiempo a las normas objeto de control. Por tanto, no puede formularse reproche alguno de validez o de eficacia a una norma estatal que ha de servir de parámetro de contraste de una norma autonómica por el hecho de que haya sido aprobada con posterioridad. Para la sentencia, igualmente, tampoco puede formularse objeción alguna a la utilización de la norma estatal propuesta como parámetro de control desde la perspectiva de los principios garantizados por el art. 9.3 CE.

2. La STC $25 / 2020$ (Pleno), de 13 de febrero, resuelve, asimismo, otro supuesto de inconstitucionalidad mediata o indirecta. 
El presidente del Gobierno interpone recurso de inconstitucionalidad contra el art. 47.1 de la Ley 7/2018, de 28 de diciembre, de Presupuestos Generales de la Comunidad Autónoma de Canarias para el ejercicio 2019, por habilitar una cuantía para el fondo de acción social de 2019 superior a la que permitiría el art. 3.Dos del Real Decreto Ley 24/2018, de 21 de diciembre, por el que se aprueban medidas urgentes en materia de retribuciones en el ámbito del sector público, que tendría, de acuerdo con su disposición adicional primera, carácter básico al amparo del art. 149.1.13 CE.

El TC resuelve el recurso en apenas cuatro meses y medio, pues fue interpuesto el día 30 de septiembre de 2019, tras no haber sido posible alcanzar un acuerdo en relación con el referido precepto en el procedimiento negociador previsto en el art. 33.2 LOTC y en el que sí se alcanzó acuerdo en relación con otros preceptos de la misma norma.

El recurso se plantea por considerar el recurrente que el incremento recogido en la ley autonómica de las cuantías de acción social — que pasan de los 6750000 euros previstos en 2018 a los 9250636 euros en 2019- es contrario a la norma básica del art. 3.Dos del Real Decreto Ley 24/2018, que prohíbe el incremento en los gastos de acción social respecto a 2018.

La sentencia constata, en primer lugar, que la prohibición de incrementar los gastos de acción social por las comunidades autónomas recogida en la norma estatal (aquí el art. 3.2 del Real Decreto Ley 24/2018) debe considerarse tanto formal como materialmente básica al amparo de los arts. 149.1.13 y 156.1 CE, pues encaja sin dificultad en los objetivos de contención de gastos de personal, priorización de las inversiones, control de la inflación y equilibrio y coordinación en el incremento de las rentas disponibles por los empleados públicos en todo el territorio nacional.

Establecido el carácter formal y materialmente básico de la norma de contraste, la sentencia constata que existe una contradicción efectiva e insalvable por vía interpretativa entre esa norma estatal de contraste y la norma autonómica recurrida, pues las cuantías de acción social pasan de los 6750000 euros previstos en la norma autonómica para 2018 a los 9250636 euros previstos en el precepto impugnado para 2019.

La sentencia declara el precepto autonómico impugnado inconstitucional y nulo, si bien, de conformidad con el motivo de inconstitucionalidad aducido y estimado, su declaración debe proyectarse tan solo sobre el exceso respecto del importe del fondo de acción social establecido en la ley de presupuestos de la comunidad autónoma para el ejercicio anterior, es decir, en cuanto el fondo de acción social constituido en la norma recurrida para el ejercicio 2019 excede de $6750000 €$ (cuantía de ese fondo en el ejercicio 2018). Así se dispone en el fallo de la STC 25/2020, que, sin embargo, en 
lugar de ser un fallo estimatorio de las pretensiones aducidas, es un fallo en el que se afirma estimar en parte el recurso y desestimarlo en todo lo demás.

Realmente uno no sabe bien en qué parte se desestima el recurso en su día interpuesto, pues, como el propio TC reconoce, lo aducido en el recurso era solo la inconstitucionalidad del exceso en la cuantía de los gastos de acción social.

La cuestión no tendría más trascendencia si no fuera por el hecho de que la comunidad autónoma fue capaz de sostener en sus notas de prensa posteriores a la sentencia que el TC había «estimado parcialmente las alegaciones efectuadas por el Gobierno de Canarias que habría conseguido consolidar un fondo de Acción Social igual al que ya se estableció en 2016 por importe de 6750000 euros». Alegación que, en los antecedentes de la sentencia, no consta que se realizase por la parte recurrida, pues, en realidad, ya el recurrente aducía que la inconstitucionalidad se refería al exceso de la cuantía para 2019 respecto de la fijada para 2018. En realidad lo que el Gobierno de Canarias alegó fue que la norma estatal de contraste no era constitucional o no era aplicable al supuesto regulado por el precepto autonómico.

Sin embargo, una aparente estimación parcial del completo motivo de inconstitucionalidad en el que se fundó el recurso de inconstitucionalidad permitió a un avezado jefe de prensa de la parte recurrida describir la resolución del TC como una suerte de decisión salomónica.

3. La STC 13/2020 (Pleno), de 28 de enero ${ }^{24}$, resuelve el recurso de inconstitucionalidad interpuesto por el presidente del Gobierno contra un buen número de los preceptos de la Ley de las Cortes de Aragón 8/2018, de 28 de junio, de actualización de los derechos históricos de Aragón.

La sentencia constata y declara que la mayor parte de la impugnación ha perdido objeto, pues los preceptos han sido ya declarados inconstitucionales y nulos por la STC 158/2019, de 12 de diciembre ${ }^{25}$, que resolvió el recurso de inconstitucionalidad interpuesto por 117 diputados del Grupo Parlamentario Popular del Congreso de los Diputados. La expulsión del ordenamiento jurídico de los preceptos impugnados determina la pérdida sobrevenida de objeto del recurso en lo que a ellos respecta.

No obstante lo anterior, cabe destacar que en aquello que no ha perdido objeto la sentencia admite que la norma autonómica pueda simplemente reproducir sin regular materias reservadas al Estatuto de Autonomía, como la capitalidad o las instituciones de autogobierno.

\footnotetext{
24 Véanse supra pp. 238-239.

25 Reseñada en Revista Española de Derecho Constitucional, núm. 118 (2020), pp. 220, $233-235$ y $253-254$.
} 
Por otro lado, la sentencia declara la inconstitucionalidad y nulidad del art. 17.2, párrafo segundo, de la norma autonómica cuando dispone que corresponde al presidente la convocatoria del referéndum de ratificación de la reforma estatutaria, por contravención con el art. 115.7 EAAr, que atribuye dicha competencia al Gobierno de Aragón y no a su presidente.

4. Por ATC 19/2020 (Pleno), de 11 de febrero, se acuerda el desistimiento en el recurso de inconstitucionalidad planteado por el presidente del Gobierno en relación con la disposición adicional segunda de la Ley de las Cortes Valencianas 21/2018, de 16 de octubre, de mancomunidades.

En el auto no constan las razones del desistimiento que sí se recogían en el Acuerdo del Consejo de Ministros por el que se solicita del presidente del Gobierno el desistimiento del recurso de inconstitucionalidad.

El TC se limita a reproducir su doctrina tradicional en relación con el desistimiento conforme con la cual puede estimarse como forma admitida para poner fin a un recurso de inconstitucionalidad, total o parcialmente, la manifestación de la voluntad de desistir, siempre que no se advierta interés constitucional que justifique la prosecución del proceso hasta su finalización por sentencia.

Sin embargo, cabe señalar que las razones del desistimiento eran relevantes a la hora de determinar la falta de interés constitucional que justifica la prosecución del recurso. Por tanto, es muy discutible que estas no aparezcan reproducidas en el auto.

En efecto, de acuerdo con la referencia del Consejo de Ministros de 21 de enero de 2020, la razón del desistimiento era la modificación de la disposición impugnada.

Tal como explica el Consejo de Ministros, con posterioridad a la interposición del recurso, el 19 de julio de 2019, la comisión bilateral Generalitat Valenciana-Estado llegó a un acuerdo por el que la Generalitat asumía el compromiso de modificar la disposición adicional segunda de la citada ley, que posibilitaba que las mancomunidades de municipios prestasen el servicio de policía local, y la Administración General del Estado asumía el compromiso de desistir del recurso una vez se produjese tal modificación.

El 30 de diciembre se publicó la Ley 9/2019, de 23 de diciembre, de medidas fiscales, de gestión administrativa y financiera y de organización de la Generalitat, que contiene la modificación legislativa de la norma autonómica pactada en la comisión bilateral y que permitiría sustentar el desistimiento del Estado. La nueva redacción excluye la creación de esos cuerpos policiales por parte de mancomunidades, por lo que ya no habría motivo para el recurso. 
Ciertamente, la modificación del precepto impugnado podía haber desembocado en su día en una sentencia de pérdida de objeto, pero el Estado ha preferido desistir. Ello supone un mensaje para evitar la conflictividad: incluso una vez interpuesto un recurso de inconstitucionalidad, cabe llegar a un acuerdo de modificación de una norma que desemboque en el desistimiento del recurso por dejar de concurrir los motivos que justificaron la interposición del recurso.

Sin embargo, el mensaje ha quedado absolutamente anulado al no recogerse en el auto las razones del desistimiento. Su falta de reproducción hace que tampoco se entienda por qué considera el TC que en el caso no se advierte un interés constitucional que justifique la prosecución del proceso hasta su finalización por sentencia, pues simplemente se afirma tal cosa sin mayor razonamiento.

5. Cabe finalmente señalar que la conflictividad por motivos competenciales en el período analizado ha continuado siendo relativamente baja.

a) Así, en el primer cuatrimestre de 2020, el presidente del Gobierno ha interpuesto tres recursos de inconstitucionalidad frente a normas autonómicas.

i) El Estado ha impugnado determinados preceptos contenidos en la reforma del derecho civil foral realizada por la Ley Foral 21/2019, de 4 de abril, de modificación y actualización de la Compilación del Derecho Civil Foral de Navarra o Fuero Nuevo. El recurso se interpone después de haber finalizado sin acuerdo el proceso de negociación previsto en el art. 33.2 LOTC.

Concretamente, el recurso interpuesto considera que las leyes 72 , 471, 483 y 544 vulnerarían la competencia estatal sobre ordenación de los registros e instrumentos públicos. Asimismo, el recurso considera que las leyes 11 y 12 de la norma navarra vulnerarían la competencia estatal sobre las normas para resolver los conflictos de leyes. Finalmente, el Gobierno considera que las leyes 511 y 495 de la norma navarra afectarían a la competencia estatal sobre las bases de las obligaciones contractuales, que es también competencia estatal exclusiva, según el art. 149.1.8. ${ }^{\mathrm{a}} \mathrm{CE}$.

ii) Asimismo, el presidente del Gobierno ha instado la interposición de un recurso de inconstitucionalidad contra el art. 19 de la Ley canaria 6/2019, de 9 de abril, de Calidad Agroalimentaria, tras haberse abierto un proceso negociador entre el Estado y Canarias (art. 33.2 LOTC) que ha concluido con acuerdo en 
relación con otros preceptos de la norma canaria, pero no en lo relativo al art. 19.

La controversia competencial radica en que el precepto de la ley canaria permite el uso del término vino para la comercialización de productos obtenidos a partir de la fermentación de frutas distintas de la uva. No obstante, el art. 2.2 e) de la Ley 24/2003, de 10 de julio, de la Vińa y del Vino, define lo que debe entenderse por vino en todo el mercado español, limitándolo al «alimento natural obtenido exclusivamente por fermentación alcohólica, total o parcial, de uva fresca, estrujada o no, o de mosto de uva». Tal y como dispone el art. 2.3 de la misma ley estatal, "las definiciones de los productos son excluyentes, no pudiendo utilizarse las respectivas denominaciones más que en los productos que se ajusten estrictamente a la definición». Para la parte recurrente esta definición estatal excluyente de vino tiene carácter de legislación básica dictada al amparo de la regla $13 .{ }^{\text {a }}$ del art. $149.1 \mathrm{CE}$, y considera que, por tanto, las comunidades autónomas no la pueden contravenir.

iii) Finalmente, el Gobierno ha instado la interposición de un recurso de inconstitucionalidad contra determinados artículos del Decreto Ley 2/2020, de 9 de marzo, de mejora y simplificación de la regulación para el fomento de la actividad productiva de Andalucía.

Más concretamente, el recurso considera, por un lado, que se ha vulnerado el régimen de los decretos leyes, y en lo que se refiere a controversias estrictamente competenciales, se interpone recurso de inconstitucionalidad contra el art. 13, que da nueva redacción al art. 33.3 de la Ley 14/2007, de 26 de noviembre, del Patrimonio Histórico de Andalucía, en el sentido de que exime de autorización previa administrativa y comunicación a la consejería competente de determinadas obras sobre bienes de interés cultural y su entorno. El Gobierno considera que esta regulación vulnera la competencia estatal en defensa de los bienes culturales contra la exportación y expoliación prevista en el art. 149.1.28 CE.

Además, se interpone recurso contra los apartados 4 y 6 del art. 28, en virtud de los cuales, respectivamente, se da nueva redacción al art. 37.b), al objeto de habilitar emisiones radiofónicas en cadena, y se suprime el art. 40 de la Ley 10/2018, de 9 de octubre, Audiovisual de Andalucía, en virtud del cual se deroga la prohibición de inclusión o 
difusión de cualquier tipo de comunicación comercial audiovisual en emisiones de personas prestadoras de servicios de comunicación audiovisual que carezcan del preceptivo título o que no hayan cumplido el deber de comunicación previo. El recurso considera que se ha producido una vulneración de las competencias estatales sobre telecomunicaciones y sobre medios de comunicación social.

b) Por parte de las comunidades autónomas se han planteado dos recursos de inconstitucionalidad frente a una misma norma estatal. Así, tanto el Parlamento de Cataluña como el Gobierno de la Generalitat de Cataluña han impugnado los arts. 1, 2, 3, 4, 6 y 7, disposición adicional única, y, por conexión, las disposiciones transitoria primera y segunda y disposición final primera del Real Decreto Ley 14/2019, de 31 de octubre, por el que se adoptan medidas urgentes por razones de seguridad pública en materia de administración digital, contratación del sector público y telecomunicaciones.

Los recursos consideran que se ha vulnerado el régimen constitucional de los decretos leyes, así como la delimitación de competencias en materia de administración electrónica y telecomunicaciones. Asimismo, se alega la posible vulneración de los arts. 18 y $20 \mathrm{CE}^{26}$.

\section{DERECHOS FUNDAMENTALES}

1. Durante este cuatrimestre se han dictado un elevado número de resoluciones sobre derechos fundamentales; entre ellas, destacan diversos recursos de amparo relacionados con la problemática suscitada como consecuencia del proceso independentista en Cataluña. Debido el elevado número de sentencias dictadas en este período y al limitado ámbito de este trabajo, a continuación, se reseńan solamente las que se han considerado más interesantes.

2. Sobre la libertad de información (art. art. 20.1.d CE), y el derecho a la propia imagen (art. $18 \mathrm{CE}$ ), con la influencia que en tales derechos pueden tener las redes sociales, la STC 27/2020 (Sala Segunda), de 24 de febrero, aborda el recurso de amparo que tenía por objeto la sentencia de la Sala de lo Civil del Tribunal Supremo a la que la editorial demandante de amparo imputaba la vulneración del derecho a comunicar libremente información veraz. Para la mercantil recurrente, la sentencia impugnada incurría en una errónea ponderación entre aquel derecho fundamental y el derecho a la propia imagen

26 Tomás de la Quadra-Salcedo Janini. 
(art. 18.1 CE), pues, a su juicio, la información por ella divulgada debía prevalecer y justificaba la difusión de la fotografía del demandado pese a carecer de su consentimiento ${ }^{27}$. Reflexiona el TC sobre la sociedad digital y la utilización no autorizada de la imagen ajena y recuerda que los usuarios de las redes sociales mantienen la titularidad de sus derechos fundamentales y que su contenido continúa siendo el mismo que en la era analógica. A continuación, el TC explica cómo funcionan internamente las redes sociales y la forma en la que se recopila la información de los millones de usuarios, advirtiendo que el usuario de la red social, solo por el hecho de serlo, puede verse abocado a perder el poder de decisión acerca de qué, cómo, dónde y cuándo desea que se difundan sus datos de carácter personal (entre ellos, la imagen). Subraya el TC que el hecho de que circulen datos privados por las redes sociales en Internet no significa que lo privado se haya tornado público, puesto que el entorno digital no es equiparable al concepto de «lugar público» del que habla la Ley Orgánica 1/1982, de 5 de mayo, de protección civil del derecho al honor, a la intimidad familiar y a la propia imagen, ni puede afirmarse que los ciudadanos de la sociedad digital hayan perdido o renunciado a los derechos protegidos en el art. $18 \mathrm{CE}$. La empresa editorial demandante de amparo entendía que la publicación de su imagen por el propio usuario en una red social en Internet y su consiguiente divulgación constituyen una suerte de consentimiento tácito para su posterior utilización por terceros. El TC no acepta esa afirmación; el consentimiento solo ampara aquello que constituye el objeto de la declaración de voluntad. El titular del derecho fundamental debe autorizar el concreto acto de utilización de su imagen y los fines para los que la otorga. Explica el TC que, si bien es cierto que el art. 2 de la Ley Orgánica 1/1982 establece que la protección civil de la propia imagen queda delimitada por los usos sociales, no puede afirmarse que don I. I. L., con la publicación de una fotografía suya en su perfil, estuviera creando en la editora

27 El 8 de julio de 2013, en la edición en papel y digital del diario La opinión-El correo de Zamora, bajo el título «Un hombre muere en Zamora al dispararse después de herir a su hermano de otro tiro", se publicó un reportaje sobre un suceso ocurrido el día anterior en el domicilio familiar (de don I. I. L.), consistente en el suicidio de su hermano tras haber previamente disparado un arma de fuego contra él, ocasionándole diversas lesiones. Don I. I. L. interpuso demanda de juicio ordinario contra La Opinión de Zamora, SA, en la que solicitaba que se dictara sentencia declarando que la publicación del reportaje había supuesto una intromisión ilegítima en el derecho fundamental a su propia imagen y a su intimidad personal y familiar (art. 18.1 CE). En el reportaje publicado en la edición en papel del diario se incluyeron sendas fotografías del demandante, don I. I. L., y de su hermano, que habían sido obtenidas de sus respectivos perfiles de la red social Facebook sin la preceptiva autorización. 
demandante de amparo la confianza de que autorizaba su reproducción en el periódico como víctima de un suceso. Tampoco acepta el TC la alegada autorización de don I. I. L. para el uso de su imagen formulada en el momento de su inscripción y registro en Facebook. Pondera a continuación el TC si la reproducción no consentida de la imagen de una persona anónima, es decir, de alguien que no es personaje público pero que adquiere repentina e involuntariamente un papel en el hecho noticiable, supuso una intromisión ilegítima en su derecho fundamental a la propia imagen. A juicio de la editora demandante de amparo, la persona de don I. I. L., en principio, simple particular, se ha proyectado puntualmente en la esfera de la opinión pública por haber protagonizado involuntariamente un suceso noticiable, y por ello es de relevancia pública dar a conocer su imagen. Recuerda el TC que la publicación de una fotografía supone una mayor intromisión en el derecho a la privacidad de la persona, pues muestra al público sus rasgos, haciéndola identificable. Ciertamente se trataba de un suceso con relevancia general, pero don I. I. L., hasta el momento en el que acaecieron los hechos de los que fue víctima, era una persona anónima y fue precisamente la difusión de su imagen la que le transformó momentáneamente en personaje público plenamente identificado, aunque su imagen carecía de todo interés general informativo, por lo que tampoco puede apreciarse su condición de accesoria a la que se refiere el art. 8.2 c) de la Ley Orgánica 1/1982 a los efectos de justificar constitucionalmente su publicación no autorizada.

Sobre el derecho al honor (art. 18 CE), la STC 28/2020 (Sala Segunda), de 24 de febrero, resolvió el recurso de amparo dirigido contra las resoluciones judiciales que no accedieron a la solicitud del recurrente de que se ordenase al Registro de la Propiedad que la anotación de prohibición de disponer que pesaba sobre un inmueble registrado a nombre de su empresa fuese alterada para suprimir la mención de los delitos por los que el recurrente, socio y administrador solidario de dicha empresa, estaba siendo investigado en dicho procedimiento penal. El recurrente no objetaba la adopción de la medida cautelar real ni tampoco el mandamiento judicial subsiguiente, sino la anotación registral a la que imputa un exceso de contenido. Invocaba, en primer término, el derecho a la presunción de inocencia. Recuerda el TC que en la STC 133/2018, de 13 de diciembre, afirmó que el derecho a la presunción de inocencia comprende el derecho a recibir la consideración y el trato de no autor o no partícipe en hechos de carácter delictivo o análogo a estos sin previa resolución dictada por el poder público u órgano competente que así lo declare. El TC considera que la anotación preventiva cautelar relativa a la prohibición de disponer no sería contraria al derecho a recibir la consideración y el trato de no autor o no partícipe en tales hechos de carácter delictivo. 
Distinta conclusión extrae sobre la alegada lesión del derecho al honor. La citada STC 133/2018 recordaba que el honor como objeto del derecho reconocido en el art. 18.1 CE es un concepto jurídico normativo cuya precisión depende de las normas, valores e ideas sociales vigentes en cada momento. El TC entiende que la información que relacione a una persona física con la investigación en fase de instrucción de hechos delictivos, aunque mantenga intacta la presunción de inocencia del afectado, conlleva o puede conllevar, teniendo en cuenta actitudes sociales que son hechos notorios, un desmerecimiento en la consideración ajena, quedando de ese modo menoscabada su reputación. El TC concluye que mencionar en la anotación registral de prohibición de disponer los delitos por los que se siguen las diligencias previas supone una afectación del derecho al honor del recurrente.

3. Con la libertad de expresión en juego (art. 20.1.a CE), destaca la STC 6/2020 (Sala Segunda), de 27 de enero, en la que el recurrente consideraba vulnerada tal libertad, al haberle impedido la dirección del centro penitenciario en el que se encontraba interno mantener una entrevista con un profesional de la prensa. De acuerdo con la motivación ofrecida por la administración penitenciaria, la justificación de la denegación se apoyaba sobre un supuesto "mal uso» de una comunicación realizada por el recluso un año antes, pues como resultado de aquella se publicó un artículo que, en opinión del centro, habría vulnerado el derecho fundamental a la intimidad de otros internos. Asimismo, explicaba la administración, se habría desacreditado a los profesionales del equipo de tratamiento mediante afirmaciones falsas acerca de su actividad laboral. Reitera el TC que las personas condenadas a una pena de prisión son titulares de las libertades de expresión e información y constata que de la legislación aplicable a las comunicaciones de los internos se extrae que la regulación referida a las comunicaciones con profesionales acreditados es poco garantista, pues no se prevén ni los casos ni las formas en que estas pueden ser denegadas. Censura el TC la interpretación llevada a cabo por la administración penitenciaria - y, después, también los órganos jurisdiccionales-, en el sentido de que el art. 51.3 LOGP prevea un tipo de comunicaciones de «autorización discrecional» por parte de la dirección del centro penitenciario. Considera la sentencia que la regulación legal de las comunicaciones controvertidas no ofrece cobertura que pueda considerarse bastante para la denegación recurrida. No comparte el TC los argumentos esgrimidos por la administración; entiende que la afectación del derecho a la intimidad de otros reclusos, a la que alude la administración penitenciaria en su resolución, no presenta en este caso la entidad suficiente para constituir un límite a su ejercicio. Por otra parte, según el acuerdo 
impugnado, el descrédito profesional de los funcionarios del centro habría afectado a su seguridad al influir en la relación de otros internos con estos profesionales. Tales argumentos, entiende el TC, resultan igualmente inhábiles para limitar la libertad de expresión e información en este caso. En primer lugar, porque, habiéndose recogido en un diario digital, difícilmente pudieron influir decisivamente esas manifestaciones en la relación de los funcionarios de prisiones con otros internos, pues estos no tienen acceso a redes de comunicación. Y, en segundo lugar, porque no se aporta en el acuerdo recurrido ni siquiera un indicio conforme al cual se pudiera prever la existencia de manifestaciones o protestas que incidieran negativamente en el buen orden interior y en la seguridad de los funcionarios. En definitiva, el TC entiende lesionado el derecho a la libertad de expresión del recurrente.

En la STC 18/2020 (Sala Primera), de 10 de febrero ${ }^{28}$, el demandante de amparo, que se encontraba interno en un centro penitenciario, fue sancionado por acuerdo adoptado por la comisión disciplinaria del indicado centro como autor de una falta grave del art. 109 a) del Reglamento penitenciario (RP) aprobado por Real Decreto 1201/1981, de 8 de mayo, por calumniar, injuriar, insultar o faltar al respeto de forma grave a funcionarios del centro, con base en las manifestaciones contenidas en sendos escritos de queja dirigidos al servicio de inspección de la Secretaría General de Instituciones Penitenciarias de los que se dio cuenta al director del centro penitenciario. Dicha sanción fue atemperada por el Juzgado de Vigilancia Penitenciaria, que calificó la falta como leve. La demanda de amparo considera que se vulneró el derecho a la libertad de expresión (art. 20.1.a CE) y la garantía del secreto de las comunicaciones (art. 18.3 CE). El TC descarta la vulneración del derecho al secreto de las comunicaciones denunciada, que se habría producido por la lectura e intervención - por el subdirector de seguridad del centro penitenciario - de sendos escritos de queja dirigidos por el demandante al servicio de inspección de la Secretaría General de Instituciones Penitenciarias. Considera el TC que no puede oponerse el secreto de las comunicaciones a quienes, interviniendo en el procedimiento administrativo iniciado, tomaron parte sucesivamente en la tramitación, ya que la CE garantiza la impenetrabilidad por terceros de las comunicaciones que se realicen a través de medios técnicos y ninguno de los funcionarios que intervinieron en dar curso a las dos instancias, ni tampoco el director del establecimiento, que era destinatario legal de sendas quejas, pueden ser considerados terceros, por lo que en modo alguno frente a ellos podía oponerse el secreto de las comunicaciones. Por otra parte, la lesión del derecho a la libertad de expresión se habría ocasionado al haber

28 Véase supra p. 231. 
sido sancionado por las expresiones utilizadas en dichos escritos en las que se limitaba a cuestionar el proceder del centro penitenciario en relación con la eventual retención de unas comunicaciones del Colegio de Abogados de Madrid a él enviadas, sin que las expresiones utilizadas fueran dirigidas a cargo alguno, teniendo por finalidad exclusiva denunciar el anormal funcionamiento del establecimiento en el que se encontraba cumpliendo condena, $\mathrm{y}$, por ello, a juicio del recurrente, estaban amparadas por el derecho invocado. Recuerda el TC que el recurrente se encontraba interno en un centro penitenciario cuando redactó de propia mano el primero de los escritos, expresando en el encabezado que los destinatarios eran el Ministerio de Interior, la Secretaría General de Instituciones Penitenciarias y la Inspección Penitenciaria. El escrito tenía por finalidad la apertura de un expediente administrativo para depurar responsabilidades. El recurrente redactó un segundo escrito remitido a los mismos destinatarios, en el cual consideraba que se había producido la nulidad en la formación de la comisión disciplinaria y en la tramitación de un expediente disciplinario contra é ${ }^{29}$. Constata el TC que el acuerdo sancionador se limitaba a reflejar alguna de las expresiones utilizadas en los dos escritos y a indicar que son constitutivas de una falta grave del art. 109 a) RP, sin atisbo alguno de ponderación, pese a que el recurrente manifestó en el pliego de descargo que sus expresiones estaban amparadas por el derecho a la libertad de expresión. Entiende el TC que las resoluciones judiciales y el acuerdo sancionador han desconocido el rigor con el que se deben ponderar los límites a los que está sometida la libertad de expresión en casos como el presente. Subraya el TC que el recurrente en sendos escritos ejercitaba su derecho de defensa y analiza los términos por los que el recurrente fue sancionado, a fin de verificar si son ajenos al ámbito protector de la libertad de expresión ejercida por un interno en un centro penitenciario mediante una queja escrita. Entiende que las expresiones utilizadas por el recurrente no pueden ser consideradas ultrajantes u ofensivas, o carentes de relación con la queja formulada, por más que su utilización pudiera molestar, inquietar o disgustar a quien estuviera encargado de tramitarla.

29 Alegaba que en el seno de un expediente disciplinario compareció ante la comisión disciplinaria, que debe estar formada por el director y otros seis miembros, pero: «[...] en lugar de dicha formación me encuentro con tres individuos, ninguno de los cuales llevaba el preceptivo y obligatorio número de funcionario en lugar visible, ni otra identificación de rango o cargo, en ningún momento se identificaron pero todos llevan chaqueta de funcionario»; y que, «[...] al no identificarse, no puedo asegurar la presencia o ausencia de jurista, pero como aquello más que una comparecencia era una inquisitoria, la indefensión está asegurada». 
Sin duda, la sentencia más destacada en este período sobre la libertad de expresión es la STC 35/2020 (Pleno), de 25 de febrero, cuyo objeto era determinar si las resoluciones judiciales impugnadas, al condenar al demandante en casación, tras una absolución previa, como autor de un delito de enaltecimiento del terrorismo, vulneraron su derecho a un proceso con todas las garantías (art. 24.2 CE), y su derecho a la libertad de expresión (art. 20.1.a $\mathrm{CE}$ ), por no haberse ponderado con carácter previo si la conducta enjuiciada suponía el ejercicio del derecho a la libertad de expresión y por no constituir las expresiones proferidas una manifestación del discurso del odio ${ }^{30}$. Descarta el TC la primera de las quejas planteadas y se centra en el análisis de la segunda, recordando su jurisprudencia sobre dicha libertad y sobre el discurso del odio, y subrayando que su labor de control queda limitada a verificar si las resoluciones judiciales impugnadas, al imponer la sanción penal, han valorado como cuestión previa si la conducta que se enjuicia constituye un ejercicio lícito del derecho fundamental a la libertad de expresión. El TC considera que la condena del recurrente ha vulnerado su derecho a la libertad de expresión, ya que, a pesar del esfuerzo desarrollado en las resoluciones impugnadas, no se ha dado cumplimiento con la suficiencia requerida a la exigencia de valoración previa de si la conducta enjuiciada era una legítima manifestación del ejercicio del derecho fundamental a la libertad de expresión. El TC constata que en las resoluciones impugnadas se hizo una referencia al uso de las nuevas tecnologías como elemento amplificador del daño e, igualmente, que se dedicó especial atención al contenido de los mensajes emitidos por el recurrente y su efecto sobre la dignidad e integridad moral de las personas mencionadas en ellos. Sin embargo, el TC considera que también estas argumentaciones resultan insuficientes, pues se observa la ausencia de consideraciones en relación con la dimensión institucional de la libertad de expresión: valoración de

30 El recurrente es cantante y letrista de los grupos de rap-metal Def Con Dos y Strawberry Hardcore. En su red social, entre noviembre de 2013 y enero de 2014, publicó los siguientes comentarios: 1) el 11 de noviembre de 2013, a las 21:06 horas: «El fascismo sin complejos de Aguirre me hace añorar hasta los GRAPO»; 2) el día 27 de enero de 2014, a las 20:21 horas: "A Ortega Lara habría que secuestrarle ahora»; 3) el día 30 de enero de 2014, a las 0:23 horas: «Street Fighter, edición post ETA: Ortega Lara versus Eduardo Madina»; 4) el día 29 de enero de 2014, a las 0:07 horas: «Franco, Serrano Suñer, Arias Navarro, Fraga, Blas Piñar... si no les das lo que a Carrero Blanco, la longevidad se pone siempre de su lado"; 5) el 20 de diciembre de 2013, a las 23:29 horas: "Cuántos deberían seguir el vuelo de Carrero Blanco», y 6) el día 5 de enero de 2014, a las 23:39 horas: «Ya casi es el cumpleaños del Rey. ¡Que emoción!», y otro usuario le dice: "Ya tendrás el regalo preparado no? Qué le vas a regalar?», a lo que contesta: «Un roscón-bomba». 
la importancia de los mensajes controvertidos desde el punto de vista de la formación de la opinión pública libre; ponderación de si tales mensajes son susceptibles de ser interpretados como manifestaciones de adhesión a opciones políticas legítimas; consideración acerca de si la condena penal de los mensajes podría producir un efecto de desaliento o acarrear la desnaturalización del derecho a la libertad de expresión, y el estudio de si el contenido y la finalidad de los mensajes son equiparables a la defensa de actitudes violentas contra el orden legal y constitucional. Frente a la falta de consideraciones de esta naturaleza, advierte el TC que en la resolución impugnada se afirma concluyentemente que resultaba irrelevante ponderar cuál era la intención -irónica, provocadora o sarcástica- del recurrente al emitir sus mensajes. Afirma el TC que no le corresponde pronunciarse sobre si la intención perseguida con los mensajes enjuiciados se integra como elemento en el tipo objeto de acusación. Ahora bien, desde la perspectiva de la exigencia constitucional de ponderar previamente la eventual concurrencia de una conducta susceptible de ser integrada en el ámbito del derecho fundamental a la libertad de expresión, aquella intención, en ausencia de otros factores que puedan ser reveladores respecto de los restantes elementos a que se ha hecho referencia, lejos de constituir una falacia, resulta ser uno de los aspectos indispensables en el análisis, pues su preterición en tales circunstancias hace definitivamente imposible ponderar si el acto comunicativo debe entenderse como realizado en el ejercicio legítimo de aquel derecho. El TC no desconoce los aspectos reprobables de los tuits formulados por el recurrente, sin embargo, estima que el imperativo constitucional de respeto a la libertad de expresión impide extraer conclusiones penales de estos elementos sin ponderar también el hecho de que los expresados tuits son susceptibles de ser interpretados como producto de la intencionalidad crítica en el terreno político y social a personas que ostentaban la condición de personajes públicos en el momento en que los actos comunicativos tuvieron lugar, y que, en uno de los casos, había tomado posición en favor de un determinado partido político. En conclusión, el TC considera que la sentencia condenatoria no ha dado cumplimiento con la necesaria suficiencia a la exigencia de valoración previa acerca de si la conducta enjuiciada era una manifestación del ejercicio del derecho fundamental a la libertad de expresión, al negar la necesidad de valorar, entre otros aspectos, la intención comunicativa del recurrente en relación con la autoría, contexto y circunstancias de los mensajes emitidos. La sentencia cuenta con un voto particular discrepante del magistrado don Alfredo Montoya Melgar.

4. En este período, el TC inadmitió por el Auto, 40/2020 (Sala Primera), de 30 de abril, el recurso planteado por los recurrentes a los que se les denegó, 
como consecuencia de la crisis sanitaria provocada por la covid-19, la posibilidad de manifestarse - en sus vehículos - el 1 de mayo. Asume el TC la especial trascendencia constitucional del recurso planteado, pero no aprecia lesión del derecho aducido. Recuerda que el derecho de manifestación (art. 21 CE) no es, como no lo es ninguno, un derecho ilimitado, y que, en el caso analizado, la limitación del ejercicio del derecho tiene una finalidad que no solo ha de reputarse como legítima, sino que, además, tiene cobertura constitucional bastante en los arts. $15 \mathrm{CE}$ (garantía de la integridad física de las personas) y $43 \mathrm{CE}$ (protección de la salud). Explica que «es aquí donde la finalidad de la medida restrictiva del ejercicio del derecho confluye con la justificación de la declaración del Estado de alarma. Las razones que sustentan ambas son idénticas y buscan limitar el impacto que en la salud de los seres humanos, en su integridad física y en su derecho a la vida pueda tener la propagación de la COVID-19». Señala el TC que no se trata aquí de garantizar el orden público o de asegurar la no alteración del orden público, sino en la garantía del derecho a la integridad física y la salud de las personas. Además, subraya que «no puede perderse de vista que el itinerario elegido por los convocantes supone ocupar durante varias horas la vía principal de circulación automovilística en Vigo, dividiendo la ciudad en dos y, eventualmente, limitando el acceso a los hospitales que se encuentran en la zona alta de la ciudad de las personas que viven en la zona más cercana a la costa». En una situación de alerta sanitaria, la libre circulación de los servicios de ambulancias o urgencias médicas, y el libre acceso a los hospitales, es un elemento que tener en cuenta a la hora de valorar la proporcionalidad de la limitación de ejercicio del derecho aquí invocado.

5. Entrando en los recursos relativos a los aspectos del art. $24 \mathrm{CE}$, destaca la STC 15/2020 (Pleno), de 28 de enero, cuyo objeto era la cuestión interna de inconstitucionalidad para determinar si el art. 454 bis.1, párrafo primero, de la Ley de Enjuiciamiento Civil, en la redacción dada por la Ley 37/2011, de 10 de octubre, de medidas de agilización procesal, vulnera el derecho a la tutela judicial efectiva (art. 24.1 CE), por crear esta norma un espacio inmune al control jurisdiccional de determinadas decisiones del letrado de la Administración de justicia ${ }^{31}$. Recuerda el TC que la redacción

31 El precepto legal cuestionado establece, al regular el recurso de revisión que debe ser resuelto por el letrado de la Administración de justicia, que «contra el decreto resolutivo de la reposición no se dará recurso alguno, sin perjuicio de reproducir la cuestión, necesariamente, en la primera audiencia ante el tribunal tras la toma de la decisión y, si no fuera posible por el estado de los autos, se podrá solicitar mediante escrito antes de que se dicte la resolución definitiva para que se solvente en ella». 
del precepto, en tanto que impide interponer contra el decreto resolutorio del recurso de reposición promovido contra las resoluciones del letrado de la Administración de justicia cualquiera de los recursos de los que podrían conocer los jueces y magistrados, es la misma que la del art. 102 bis.2, párrafo primero, de la Ley 29/1998, de 13 de julio, reguladora de la jurisdicción contencioso-administrativa, y del art. 188.1, párrafo primero, de la Ley 36/2011, de 10 de octubre, reguladora de la jurisdicción social, declarados inconstitucionales y nulos por contradecir el derecho a la tutela judicial efectiva, respectivamente, por las SSTC 58/2016, de 17 de marzo, y 72/2018, de 21 de junio $^{32}$. Considera el TC que el precepto analizado contiene una singularidad, como es el hecho de que la posibilidad impugnatoria es la de reproducir la cuestión controvertida en la primera audiencia ante el tribunal tras la toma de la decisión y, si no fuera posible por el estado de los autos, solicitándolo mediante escrito antes de que se dicte la resolución definitiva para que se solvente en ella. En cualquier caso, entiende el TC que el artículo analizado vulnera el art. 24.1 CE, puesto que su redacción no permite descartar la eventualidad de que existan supuestos en que la decisión del letrado de la Administración de justicia excluida por el legislador del control judicial — directo o indirecto- concierna a cuestiones relevantes en el marco del proceso que atañen a la función jurisdiccional reservada en exclusiva a jueces y magistrados, y que, por tanto, deben quedar sometidos a su posibilidad de control de acuerdo con el derecho a la tutela judicial efectiva sin indefensión que a todos garantiza el art. 24.1 CE. Posteriormente, en la STC 17/2020 (Sala Segunda), de 10 de febrero, se estimó el amparo que había dado lugar a la cuestión interna de constitucionalidad. En similares términos, la STC 33/2020 (Sala Segunda), de 24 de febrero.

En la STC 26/2020 (Sala Primera), de 24 de febrero, se planteaba como problema principal y novedoso el análisis de si la aplicación que hizo el órgano judicial del Reglamento (CE) núm. 805/2004 del Parlamento Europeo y del Consejo, de 21 de abril de $2004^{33}$, vulneró o no el derecho a la tutela judicial

32 Una cuestión similar se examina en el procedimiento resuelto por la STC 34/2019, de 14 de marzo, en que se declararon inconstitucionales y nulos, por vulneración del art. 24.1 CE, el art. 34.2, párrafo tercero, y el art. 35.2, párrafos segundo y cuarto, LEC, por no permitir recurso contra las decisiones de esta naturaleza dentro del procedimiento de jura de cuentas.

33 El Reglamento (CE) núm. 805/2004 del Parlamento Europeo y del Consejo, de 21 de abril de 2004, establece un título ejecutivo europeo para créditos no impugnados, y establece un modelo de reconocimiento de títulos ejecutivos basado en el principio de reconocimiento mutuo que se aplica en materia mercantil y civil. 
efectiva del recurrente. Se solicitaba al TC que valorara si la interpretación realizada por el órgano judicial, librando la certificación de un título ejecutivo notificado por edictos, lesiona el derecho a la tutela judicial efectiva por incurrir en error patente, manifiesto y arbitrario al confundir las normas mínimas aplicables a los procedimientos para que se pueda emitir un certificado del título ejecutivo europeo, de acuerdo con la normativa comunitaria y que se integran en el propio derecho de defensa, con las normas procesales internas que eventualmente puedan permitir el emplazamiento por edictos. Por lo que interesa al recurso planteado, el examen se refería a las garantías de la notificación con el ánimo de asegurar que en el procedimiento previo a la adopción de la resolución cuya certificación se solicita se respetaron los derechos de audiencia y defensa de la parte deudora. Este examen se reserva a supuestos en los que la no comparecencia del demandado en el procedimiento supone una asunción tácita del crédito que permite calificarlo como crédito no impugnado a los efectos de la aplicación del reglamento. En lo que se refiere a la notificación sin acuse de recibo (art. 14 del reglamento), respecto de la que el reglamento describe varias modalidades admisibles, solo será válida si se conoce con certeza el domicilio del deudor. Con estas previsiones, el reglamento establece un parámetro mínimo de garantía del derecho de defensa que asegure que la ausencia del deudor fue consciente y voluntaria, de lo que se puede deducir la ausencia de ánimo de impugnar el crédito. El problema es determinar si una notificación por edictos efectuada desconociendo totalmente el domicilio del deudor, que puede resultar eventualmente válida desde la óptica del art. 24.1 CE, es también válida desde la perspectiva del art. 47 CDFUE para librar una certificación de título ejecutivo europeo. La respuesta a este interrogante, teniendo en cuenta el considerando 13 del Reglamento 805/2004 y la jurisprudencia del Tribunal de Justicia en el asunto $G$ contra Cornelius de Visser, de 15 de marzo de 2012, debe ser negativa según el TC. El Tribunal de Justicia de la Unión Europea ha considerado que, si bien una sentencia en rebeldía figura entre los títulos ejecutivos que pueden ser certificados como títulos ejecutivos europeos, cuando esta ha sido dictada sin determinar el domicilio del demandando no puede ser certificada como título ejecutivo europeo. Por tanto, el «derecho de la Unión debe interpretarse en el sentido de que se opone a la certificación, como título ejecutivo europeo en el sentido del Reglamento núm. 805/2004, de una sentencia en rebeldía dictada contra un demandado cuyo domicilio sea desconocido». Considera el TC que el órgano judicial nacional debió tener en cuenta la doctrina expuesta a la hora de verificar el cumplimiento de los requisitos para certificar el título ejecutivo europeo, actuando como juez de garantías de la Carta Europea de Derechos Fundamentales, además de hacerlo como órgano de garantía de los derechos fundamentales contenidos en la CE. La cuestión concreta que debió haberse planteado el Juzgado 
de lo Mercantil se refería a si la notificación edictal sin conocer el domicilio del deudor, que fue la única que intentó respecto del recurrente en amparo, cumplía o no las exigencias derivadas del art. $47 \mathrm{CDFUE}$. Considera el TC que el órgano judicial actuó de forma errónea, porque, más allá de que la notificación edictal fuera o no adecuada en términos de respeto al derecho a la tutela judicial efectiva constitucionalmente reconocido, es indudable que no lo era en términos del derecho de defensa y de audiencia contemplado en el art. 47 CDFUE. Y al realizar este juicio erróneo, el órgano judicial ha incurrido en vulneración del art. 24.1 CE en el sentido denunciado por el recurrente ${ }^{34}$.

En la STC 34/2020 (Sala Segunda), de 24 de febrero ${ }^{35}$, la demanda de amparo alegaba que la resolución judicial impugnada incurrió en vulneración del art. 24.1 CE, porque acordó denegar la solicitud de declaración de nulidad de la subasta para subsanar el error advertido en el anuncio publicado, pese a que la categoría asignada al inmueble objeto de licitación, la de "local comercial», era errónea y limitaba la publicidad y transparencia e incumplía de manera palmaría las normas que rigen las subastas electrónicas, por lo que debería haber sido corregida por la de "solar», que era la que realmente le correspondía. Considera el TC que no se pone en cuestión que se cometiera un error en el anuncio de la subasta del bien controvertido, quedando constreñido el debate a la relevancia de este. La efectividad del derecho a la tutela judicial efectiva, que ha de procurarse mediante el cumplimiento por el órgano judicial de su deber legal de respetar lo que la ley dispone para la realización de bienes en el procedimiento ejecutivo, no puede desconocerse desviando a los recurrentes la carga de soportar los eventuales perjuicios que la incorrección de la publicidad pueda acarrear para el curso de la subasta. Constata el TC que el juzgado desatendió manifiestamente la relevancia del error del anuncio de la subasta y la incidencia en el proceso de realización forzosa del bien que ese defecto en su identificación podía conllevar, aunque se lo pusiera de manifiesto la parte demandante de amparo a la vista de la regulación contenida en la de la Ley de Enjuiciamiento Civil.

6. A continuación, se reseñan brevemente algunos de los recursos de amparo relacionados con la problemática suscitada como consecuencia de proceso

34 El TC recuerda que ya afirmó en la STC 232/2015, de 5 de noviembre, que «el desconocimiento y preterición de esa norma de Derecho de la Unión, tal y como ha sido interpretada por el Tribunal de Justicia, puede suponer una "selección irrazonable y arbitraria de una norma aplicable al proceso", lo cual puede dar lugar a una vulneración del derecho a la tutela judicial efectiva».

35 Véase supra p. 231. 
independentista en Cataluña. En la STC 3/2020 (Pleno), de 15 de enero, se analizó el recurso planteado contra el acuerdo de prisión provisional del recurrente, exdiputado del Parlamento de Cataluña, por hechos presuntamente constitutivos de delito de rebelión, al apreciar la concurrencia de riesgos de reiteración delictiva y fuga. El TC desestima el recurso de amparo considerando que, respecto de la alegada vulneración del derecho a la libertad personal, las resoluciones recurridas se encuentran debidamente fundadas remitiendo a la doctrina de las SSTC 62/2019, de 7 de mayo, y 155/2019, de 28 de noviembre. También rechaza la alegada vulneración a la libertad ideológica y a la participación política ya que constata que la adopción de la prisión provisional de basó en el pronóstico de reiteración delictiva y no en su ideología política. Se remite el TC a la STC 155/2019 para rechazar la alegada vulneración del derecho al ejercicio del cargo público. La sentencia cuenta con un voto particular discrepante formulado por los magistrados don Juan Antonio Xiol Ríos y don Fernando Valdés Dal-Ré.

En la STC 4/2020 (Pleno), de 15 de enero, se analiza la denegación al recurrente de un permiso penitenciario extraordinario para intervenir en su investidura parlamentaria como candidato a la presidencia de la Generalitat de Cataluña. El TC rechaza el recurso remitiéndose a la STC 155/2019, para desestimar la vulneración del derecho a la participación y a la representación política, al considerar que la ponderación efectuada por las resoluciones judiciales impugnadas es conforme con las exigencias de proporcionalidad en la afectación a los derechos fundamentales. En segundo lugar, desestima la vulneración del derecho a la presunción de inocencia, ya que ninguna de las dimensiones fijadas por la doctrina del TC que protegen este derecho resultaron desconocidas. La sentencia cuenta con un voto particular discrepante formulado por los magistrados don Juan Antonio Xiol Ríos y don Fernando Valdés Dal-Ré. En términos similares, las SSTC 9/2020 (Pleno), de 28 de enero, y 23/2020 (Pleno), de 13 de febrero ${ }^{36}$.

En la STC 5/2020 (Pleno), de 15 de enero, se desestima el recurso de la expresidenta del Parlamento de Cataluña en aplicación de la doctrina sentada en las SSTC 29/2019 y 30/2019, ambas de 28 de febrero, por considerar que la prisión provisional adoptada tiene fundamento en un presupuesto adecuado y persigue un fin constitucionalmente legítimo. Se inadmite el recurso por falta de invocación previa en lo referente al derecho al juez ordinario y al proceso con todas las garantías. En la STC 11/2020 (Pleno), de 28 de enero, se aborda la decisión del magistrado instructor, que acordó mediante auto comunicar a la Mesa del Parlamento de Cataluña la suspensión de los cargos que estaban desempeńando los recurrentes, por haber devenido firme el auto

36 Véanse supra p. 237. 
de procesamiento. El art. 384 bis de la Ley de Enjuiciamiento Criminal establece la suspensión de las funciones de los cargos públicos en aquellos casos en los que el auto de procesamiento sea firme en causas de terrorismo o rebeldía, y se haya decretado la prisión provisional. Se cuestionaba la aplicación del precepto al discutirse la firmeza del auto de procesamiento. Considera el TC que el auto de procesamiento es firme al no poder ser recurrido. Asimismo, constata que las resoluciones impugnadas cumplen el deber reforzado de motivación y el juicio de adecuación en tanto que afectan a derechos fundamentales. En términos similares, la STC 38/2020 (Pleno), de 25 de febrero ${ }^{37}$.

En la STC 36/2020 (Pleno), de 25 de febrero ${ }^{38}$, el TC desestimó el recurso de amparo presentado contra varias resoluciones del Tribunal Supremo que denegaron al recurrente los permisos extraordinarios de salida solicitados para acudir a dos actos de campańa de su candidatura en las elecciones al Parlamento de Cataluńa. Explica el TC que no se vulneró su derecho a la participación directa en asuntos públicos y al acceso de cargos públicos en condiciones de igualdad (art. $23 \mathrm{CE}$ ), ya que tal derecho no es, en sí mismo, obstáculo que impida acordar o mantener en el tiempo la prisión provisional de un parlamentario cuando concurran las condiciones constitucionales y legales que la hacen legítima. Respecto a la queja del recurrente de que se ha visto privado de su derecho a mantener comunicaciones orales y escritas con el exterior, la sentencia señala que no es cierto, porque sí pudo mantenerlas conforme a las pautas ordinarias que definen el régimen interno del centro penitenciario. La sentencia concluye avalando la decisión acordada por el Tribunal Supremo en el sentido de no ampliar el régimen ordinario de comunicaciones personales del demandante o su conexión a Internet, ya que "posibilitaría las situaciones de riesgo que la prisión ha tratado de conjurar, pues no sólo facultarían el impulso de movilizaciones inmediatas, sino que pueden aprovecharse para propiciar que los tumultos se materialicen en respuesta a la conformación institucional que resulte de los comicios». La sentencia cuenta con un voto particular discrepante formulado por los magistrados don Juan Antonio Xiol Ríos, don Fernando Valdés Dal-Ré y la magistrada dońa María Luisa Balaguer Callejón.

En la STC 37/2020 (Pleno), de 25 de febrero, se desestiman los recursos de amparo interpuestos contra el auto del Tribunal Supremo que decretó la prisión provisional, comunicada y sin fianza de los demandantes. La sentencia explica que no ha existido una lesión del derecho a la libertad personal de los recurrentes derivada de la insuficiencia de las razones dadas por el Tribunal

37 Véanse supra p. 237.

38 Véanse supra p. 237. 
Supremo para acordar la medida de prisión preventiva, sino que estaba justificada por la existencia de indicios racionales basados en unos hechos presuntamente constitutivos de delitos graves. El TC razona que «no se puede calificar de desproporcionada la injerencia de la medida de prisión provisional, teniendo en cuenta el momento en el que se han dictado las resoluciones judiciales impugnadas y las circunstancias concurrentes en este caso, relativas a la entidad de los hechos investigados y a la participación de los recurrentes». La sentencia recuerda que las limitaciones que los demandantes de amparo denuncian en el desempeño de sus funciones como parlamentarios «derivan indefectiblemente de su situación de privación de libertad, ya que parte de las facultades de representación política anejas al cargo quedan afectadas por la situación de prisión provisional». Por último, el TC también ha valorado desde la perspectiva de control constitucional el hecho de que los recurrentes podrían impugnar a través de los recursos legales previstos la medida cautelar de prisión y delegar su voto si la Mesa de la Cámara no encontraba motivo alguno para oponerse a ello. La sentencia cuenta con un voto particular discrepante formulado por los magistrados don Juan Antonio Xiol Ríos, don Fernando Valdés Dal-Ré y la magistrada doña María Luisa Balaguer Callejón ${ }^{39}$.

39 Carlos Ortega Carballo. 